\title{
A segunda Lei de Newton: teoria versus aplicação no cotidiano
}

\author{
Newton's second law: theory versus application in everyday life \\ Segunda ley de Newton: teoría versus aplicación en la vida cotidiana
}

Recebido: 17/06/2020 | Revisado: 01/07/2020 | Aceito: 01/02/2021 | Publicado: 07/02/2021

Antonio Marques dos Santos
ORCID: http://orcid.org/0000-0003-2822-0710
Instituto Federal de Educação, Ciência e Tecnologia do Rio Grande do Norte, Brasil
E-mail: antonio.marques@ ifrn.edu.br
Jade Souza da Silva
ORCID: http://orcid.org/0000-0002-4812-3451
E-mail: jadesouzadasilva@ gmail.com

\begin{abstract}
Resumo
O presente trabalho tem como principal objetivo despertar nos alunos o interesse pela física e seus fenômenos da natureza, de modo que o aluno poderá ter mais curiosidade em observar seu cotidiano, e associar a física à sua vida. As leis de Newton estão bastante presentes no nosso cotidiano, já que elas abordam os conceitos de força e massa. Todos os dias observamos vários tipos de movimento: MRU, MRUV, MCU e etc., movimentos que se alteram a cada instante. Estas alterações no movimento são determinadas pela força resultante e pela massa dos corpos, gerando assim uma aceleração. A lei física responsável pela explicação de tal fenômeno é a segunda lei de Newton. Para a realização desse trabalho, será aplicado um questionário na turma de 1 ano do ensino médio na escola Centro de Ensino Josélia Ramos de Almeida, em São João dos Patos - Maranhão. Os alunos irão observar todos os fenômenos físicos durante sua rotina, no período de uma semana. E em seguida irão associar quais fenômenos estão relacionados com a segunda lei de Newton, podendo assim, compreender que as explicações para muitas atividades realizadas, muitos fenômenos que ocorrem e fazem parte da sua vida cotidiana podem ser explicados pela física. Os resultados obtidos foram satisfatórios, pois os alunos abraçaram o trabalho e se mostraram bastante interessados em participar do mesmo. Eles conseguiram enxergar a física ao seu redor, puderam comprovar que realmente a física faz parte do seu cotidiano.
\end{abstract}

Palavras-Chaves: Cotidiano; Ensino de Física; Segunda Lei de Newton.

\begin{abstract}
The present work has as main objective to awaken in students an interest in physics and its natural phenomena, so that the student may be more curious to observe his daily life, and associate physics with his life. Newton's laws are very present in our daily lives, since they address the concepts of force and mass. Every day we observe several types of movement: MRU, MRUV, MCU and etc., movements that change from moment to moment. These changes in movement are determined by the resulting force and the mass of the bodies, thus generating an acceleration. The physical law responsible for explaining such a phenomenon is Newton's second law. In order to carry out this work, a questionnaire will be applied to the 3 year class of high school at the Centro de Ensino Josélia Ramos de Almeida, in São João dos Patos - Maranhão. Students will observe all physical phenomena during their routine, within a week. And then they will associate which phenomena are related to Newton's second law, thus being able to understand that the explanations for many activities performed, many phenomena that occur and are part of their daily life can be explained by physics. The results obtained were satisfactory, as the students embraced the work and were very interested in participating in it. They were able to see the physics around them, they could prove that physics is really part of their daily lives.
\end{abstract}

Keywords: Daily; Physics teaching; Newton's Second Law.

\section{Resumen}

El presente trabajo tiene como objetivo principal despertar en los estudiantes un interés en la física y sus fenómenos naturales, para que el estudiante tenga más curiosidad por observar su vida diaria y asociar la física con su vida. Las leyes de Newton están muy presentes en nuestra vida diaria, ya que abordan los conceptos de fuerza y masa. Todos los días observamos varios tipos de movimiento: MRU, MRUV, MCU, etc., movimientos que cambian de un momento a otro. Estos cambios en el movimiento están determinados por la fuerza resultante y la masa de los cuerpos, generando así una aceleración. La ley física responsable de explicar tal fenómeno es la segunda ley de Newton. Para llevar a cabo este trabajo, se aplicará un cuestionario a la clase de secundaria de 3 años en el Centro de Ensino Josélia Ramos de Almeida, en São João dos Patos - Maranhão. Los estudiantes observarán todos los fenómenos físicos durante su rutina, dentro de una semana. Y luego asociarán qué fenómenos 
están relacionados con la segunda ley de Newton, pudiendo comprender que las explicaciones de muchas actividades realizadas, muchos fenómenos que ocurren y son parte de su vida diaria pueden explicarse por la física. Los resultados obtenidos fueron satisfactorios, ya que los estudiantes aceptaron el trabajo y estaban muy interesados en participar en él. Pudieron ver la física a su alrededor, pudieron demostrar que la física es realmente parte de su vida cotidiana.

Palabras clave: Diario; Didáctica de la física; La segunda ley de Newton.

\section{Introdução}

O baixo desempenho dos alunos na disciplina de Física está ficando cada vez mais constante em decorrência dos paradigmas de que tal disciplina, é "difícil”, "complicada de ser entendida", etc. Concepções como essas vêm se disseminando de geração em geração.

Essas questões vêm contribuindo para o baixo índice de aprovação e também para falta de interesse dos alunos, e dos próprios professores pela disciplina. Sabemos que para uma melhor compreensão e entendimento da disciplina em si, é necessário que os professores relacionem os assuntos ministrados com situações ocorridas no dia a dia dos alunos. Existem trabalhos e livros que associam a Física ao nosso cotidiano, como por exemplo: A importante da Física Experimental no cotidiano e na educação, Capelari, D.\& Zukovski, S.N.S., (2009). Física do Dia-a-Dia: 105 perguntas e respostas sobre Física fora da sala de aula, Carvalho, R.P. (2003), A Física na Cozinha, Migliaavacca, A. \& Witte, G. (2014).

Diante disso, vale ressaltar que o ensino da física vem sendo trabalhado na maioria das vezes utilizando apenas o livro didático, não que este não seja importante porém existem outras ferramentas que podem ser utilizadas, ou seja, os professores não buscam se auto avaliar ou melhorar suas metodologias de ensino, o que pode dificultar em grande instância o desenvolvimento do discente.

Com isso, faz-se necessário que os professores avancem no uso de novas metodologias com isso, uma vez que o ensino precisa de novas técnicas para obter um melhor desempenho de aprendizagem, atendendo as necessidades gerais dos alunos.

A física dispõe de muitos conteúdos importantes, e contou com a contribuição de muitos teóricos influentes como: (Galileu Galilei-Descobridor das leis dos corpos e introdutor do princípio da inércia; Benjamin Franklin- pelas experiências com a eletricidade e por ter descoberto as cargas positivas e negativas; Albert Einstein-propositor da teoria da relatividade e ganhador do prêmio Nobel de física em razão das explicações sobre efeito fotoelétrico), etc.. e Isaac Newton, que contribuiu em diversas áreas da matemática e da física. Na matemática por exemplo, com a criação do Cálculo Diferencial e Integral e na física com as três leis que descrevem o movimento dos corpos, (talvez uma das contribuições mais importantes de Newton), que ficaram conhecidas como as Leis de Newton.

Essas leis foram publicadas pela primeira vez em sua obra Philosopiae Naturalis Principia Mathematica ("Princípios Matemáticos da Filosofia Natural”). Tal obra se tornou mais conhecida depois que Newton recebeu uma visita do Jovem Astrônomo Edmond Halley que se deslocou de Londres até Cambridge objetivando interrogar Newton, com o seguinte questionamento: Como Newton explicaria o movimento dos planetas, observado pelos astrônomos a partir das leis da física? Assim como Edmond Halley questionou Newton, na escola os alunos fazem os seguintes questionamentos: Aonde vou usar isso na minha vida? Para que serve física? os mesmos não se dão conta de que a física e seus fenômenos naturais são de suma importância para a sua aprendizagem e acabam não se importando com tais conteúdos que dizem respeito a mesma. Com isso, nossa proposta busca mostrar aos alunos que as grandezas força (vetorial) e massa (escalar) são itens bastante colaborativos e participativos na nossa vida, e no caso a explicação mais precisa que eles podem ter para a realização de forças e a utilidade de massa, é a segunda lei de Newton. 


\section{Metodologia}

Este trabalho foi desenvolvido na escola Centro de Ensino Josélia de Almeida Ramos, nas turmas (101 composta por 24 alunos e 102 composta por 35 alunos) de $1^{\circ}$ ano do ensino médio, na cidade de São João dos Patos - MA. Para realização deste trabalho, foram realizadas observações feitas em relação aos fenômenos naturais que vivenciamos no cotidiano. Vale ressaltar que o presente artigo é de caráter qualitativo e quantitativa.

Segundo Triviños (1987), a pesquisa qualitativa trabalha de forma a buscar seu significado, baseando-se perceptivelmente dentro do contexto em que determinado fenômeno ou alvo pesquisado está inserido. O que se almeja nos resultados da pesquisa qualitativa, além de suas essências é também a raiz de tal fenômeno, seus traços de origem, suas evoluções até o tempo presente da pesquisa. Com isso, uma das abordagens metodológicas utilizada nesse trabalho foi de caráter qualitativo, visto que nossa proposta visou estabelecer uma relação dinâmica entre o mundo real e o público alvo que foi envolvido na pesquisa na qual vivenciaram os fenômenos para depois abordar seus conceitos sobre estes.

A pesquisa de caráter quantitativo, pois, a coleta de dados foi feita com um questionário de verificação de aprendizagem com questões relacionadas ao conteúdo em questão, buscando observar o nível de conhecimento e interesse dos alunos em relação a física, tal questionário foi aplicado de forma estruturada com perguntas objetivas e subjetivas, referentes às experiências alcançadas com a proposta do nosso trabalho, e finalmente foi aplicado um último questionário para colher as informações que fazem parte do processo de coleta de dados.

Na pesquisa de campo primeiramente foi realizada uma visita à escola para esclarecer ao professor da disciplina de física e aos alunos das turmas primeiro ano 101 e 102 respectivamente, e assim pedir permissão à estes para a realização da pesquisa. Com isso, todos os alunos e pais responsáveis pelos alunos menores de 18 anos assinaram um termo de consentimento, onde concordaram com a execução da pesquisa na escola, o que também permitia a utilização dos dados, fotos e atividades realizadas para a obtenção da coleta de dados.

O intuito e objetivo da pesquisa foi propor aos alunos do $1^{\circ}$ ano do ensino, que observassem toda a trajetória do seu cotidiano durante o período de uma semana, e analisassem os principais acontecimentos nas atividades praticadas no seu dia a dia, e em seguida associassem quais fenômenos estão relacionados com a segunda lei de Newton. Trazendo para a sala de aula, os relatos das informações colhidas durante as observações feitas. Podendo assim, compreender que há explicações para muitos acontecimentos, muitos fenômenos que ocorrem e fazem parte da sua vida cotidiana e que, portanto, essas explicações e respostas se dão por meio dos fenômenos físicos naturais.

A proposta também destaca que melhor seria se os alunos tivessem uma progressão dos conhecimentos já obtidos sobre a física e a Mecânica Newtoniana, ficando assim mais fácil de obter a coleta de dados, com isso poderiam associar as situações observadas no referido tempo, e construir seus próprios conceitos com relação ao assunto em questão. A partir das dúvidas e questionamentos que os alunos fizessem sobre a experiência proposta, instigaríamos estes a relacionarem, a expressarem suas opiniões a respeito, e analisarem quais as contribuições da segunda Lei de Newton para os fenômenos até então observados.

No entanto, o presente trabalho buscou mostrar a relevância da segunda lei (Princípio Fundamental da Dinâmica), fazendo com que os alunos pudessem relacionar suas atividades à determinada lei e observar em quais situações do seu cotidiano ela se faz presente. Tal experiência é muito relevante porque pode fazer com que os alunos se interessem mais em buscar respostas para os fenômenos físicos que acontecem no seu dia a dia, percebendo a grande relevância e aplicabilidade da disciplina de física e assim enxergar a presença desta nas atividades diárias, desde as mais simples que praticamos, até as mais 
complexas. Desse modo, enfatizou-se que fosse acrescentado ao aluno um maior incentivo para estudar e conhecer um pouco mais sobre a importância da disciplina.

Além de mostrarmos a importância e aplicabilidade da segunda lei de Newton, nossa experiência propôs uma nova metodologia de ensino, além do tradicional onde o professor explana os conteúdos do livro didático e os alunos só reproduzem o que o professor faz, ou seja, mostramos um outro método para fazer com que os alunos se interessem mais pela disciplina e aprendam de uma forma clara e interessante, pois sabemos que é notório que a aula se torna mais produtiva quando os alunos são convidados a participar, ou seja, quando o professor trabalha de forma dinâmica e criativa.

A experiência aqui proposta para esses alunos tratou justamente de uma forma destes se tornarem autores de suas práticas e assim poder relacionar a teoria já conhecida com a prática em questão, isto é, transformar tudo aquilo que se encontra no seu cognitivo por meio de pensamentos, em experiências vivenciadas por meio de práticas constatadas.

Tal experiência pode levá-los a várias indagações como: Porque tais fenômenos ocorrem? Quais as explicações físicas para os mesmos? Uma vez que os alunos fazem tais questionamentos, já estão em processo de construção de conhecimento, ou seja, estão buscando explicações físicas para a existência desses fenômenos. Quando curiosidades como essas começam a ser despertadas nos alunos, é sinal de que a disciplina está tendo um significado mais amplo e eficaz.

É justamente nesse contexto que pode está a grande diferença em trazer a física para o cotidiano e relacioná-la com o dia a dia, pois quando é feita essa ligação, o professor está oportunizando o aluno a pensar e se imaginar dentro de determinada situação descrita. E com isso, o aluno vai construindo seu próprio conhecimento.

\subsection{Caracterização do local Pesquisado}

A escola estadual Centro de Ensino Professora Josélia de Almeida Ramos, localizada na cidade de São João dos Patos - Maranhão, na Rua Hermes da Fonseca Bairro São Raimundo. Os horários de funcionamento são manhã, tarde e noite, ambos com ensino médio.

A infraestrutura possui água filtrada e energia da rede pública e o lixo destinado à coleta periódica. Com relação às dependências possui: uma sala de diretoria, sete salas de aulas, um laboratório de informática, uma sala de recursos multifuncionais para atendimento educacional especializado (AEE), alimentação escolar para os alunos, uma cozinha, banheiro masculino e feminino dentro do prédio, uma despensa, pátio coberto.

\subsection{Característica dos Sujeitos}

A turma (101) de primeiro ano, turno matutino é composta por 26 alunos, e, portanto, a pesquisa foi realizada com 22 alunos, a sala dispondo de meninas e meninos em idade escolar entre 15 e 17 anos. A turma (102) de primeiro ano, turno matutino é composta por 36 alunos, a realização da pesquisa também se deu com os 33 alunos, a sala dispondo de meninas e meninos em idade escolar entre 15 e 20 anos, dentre eles um é altista. Tanto na turma 101, quanto na turma 102 faltaram alunos no dia da coleta dos dados que o justifica a quantidade de alunos que fizeram parte da pesquisa.

\subsection{Instrumentos de coleta de dados}

No primeiro encontro apresentado objetivo da pesquisa novamente e entregue os termos de consentimento, em anexo, a cada aluno, para que os principais responsáveis tivessem consciência sobre o envolvimento dos seus filhos com a pesquisa. No segundo encontro foi entregue o questionário, com perguntas (que se encontra em anexos) referentes ao conhecimento e experiências dos alunos quanto à segunda Lei de Newton. No terceiro encontro, foi recolhida as anotações dos alunos com 
informações sobre as observações feitas. E finalmente, no último encontro foi entregue aos alunos um último questionário com questões subjetivas sobre os conhecimentos adquiridos por estes durante a pesquisa sobre a Segunda Lei de Newton.

\section{Resultados e Discussão}

O primeiro encontro ocorreu com a turma 101, o primeiro contato com os alunos se deu a partir de um questionamento aos discentes sobre o que eles entendem quanto a segunda Lei de Newton. Em seguida, antes de iniciarmos a pesquisa, foi pedido que eles se pronunciassem a respeito, com o intuito de fazer com que estes viessem a colocar seus conhecimentos prévios em prática, ou até relatar experiências já vivenciadas no âmbito escolar e no seu cotidiano relacionados ao conteúdo da pesquisa. Como resposta os 22 alunos ali presentes, responderam que haviam visto sim o conteúdo ainda que não tivesse sido de forma aprofundada, mas que tinham interesse em aprender mais a respeito. Desses que responderam, alguns relacionaram a segunda Lei de Newton com força e aceleração de corpo, e os outros afirmaram ter visto mas não aprenderam nada a respeito, porém é importante lembrar que, alguns afirmaram nunca ter estudado o conteúdo. Com isso, pode-se afirmar que:

O primeiro encontro ocorreu com a turma 101, o primeiro contato com os alunos se deu a partir de um questionamento aos discentes sobre o que eles entendem quanto a segunda Lei de Newton, em seguida foi pedido que eles se pronunciassem a respeito, com o intuito de fazer com que estes viessem a colocar seus conhecimentos prévios em prática, ou até relatar experiências já vivenciadas no âmbito escolar e no seu cotidiano relacionados ao conteúdo da pesquisa, antes de iniciarmos a pesquisa. Como resposta, os 22 alunos ali presentes, responderam que haviam, visto sim o conteúdo, ainda que não tivesse sido de forma aprofundada, mas que tinham interesse em aprender mais a respeito. Desses que responderam, alguns relacionaram a segunda Lei de Newton com força e aceleração de corpo, e os outros afirmaram ter visto, mas não aprenderam nada a respeito, mas é importante lembrar que, alguns responderam não estudaram o conteúdo. Com isso, pode-se afirmar que:

Gráfico 1: Posição dos alunos da turma 101 quanto a segunda Lei de Newton.

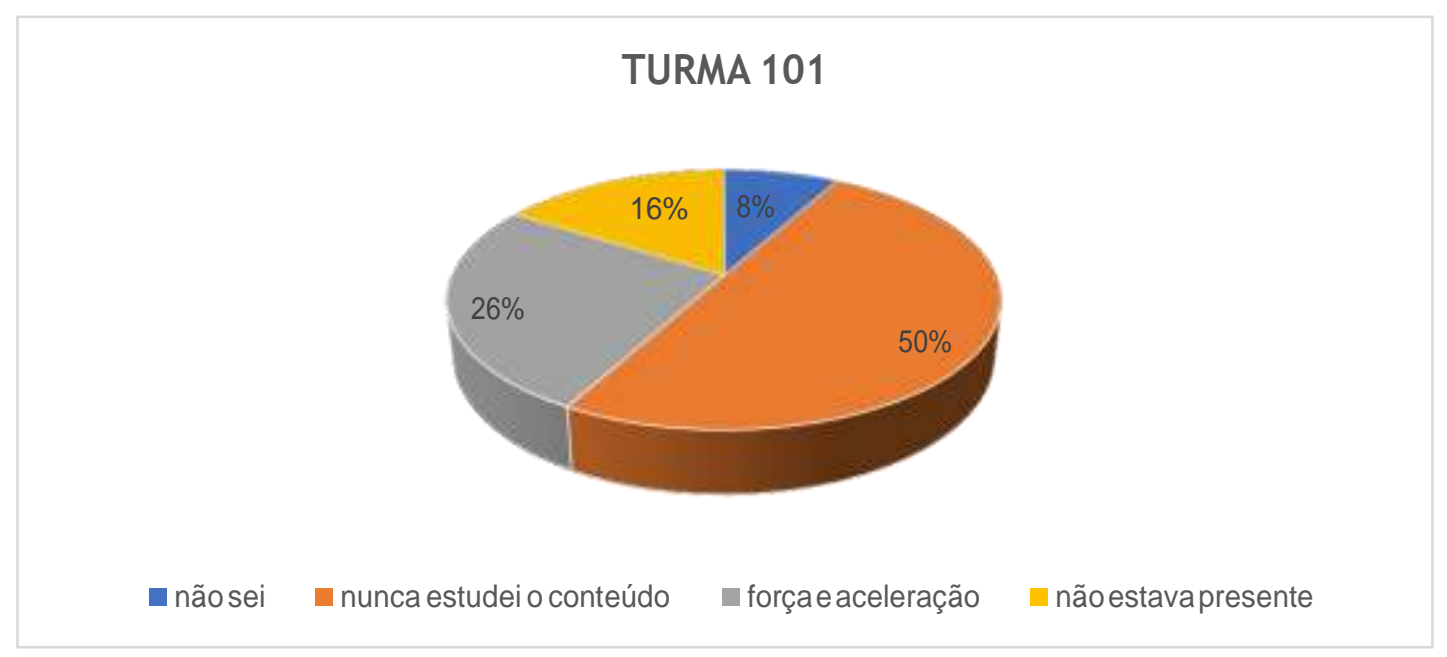

Fonte: Autores (2018).

A mesma pergunta foi feita para a turma também de primeiro ano, turma 102, e alguns dos 33 alunos presentes responderam que o conteúdo já havia sido explanado pelo professor, 
mas que não haviam se aprofundado ou dado importância em aprender a respeito, e que para eles tratou-se apenas de mais um conteúdo que o professor havia explorado, mas disseram que o conteúdo estava relacionado à força aplicada sobre um corpo, e complementaram ser a única coisa que aprenderam sobre o conteúdo, além disso, a maioria dos alunos afirmaram não saber ou não dominarem o conteúdo em questão como resultado significativo da referida turma, tem- se que:

Gráfico 2: Posição dos alunos quanto a segunda Lei de Newton.

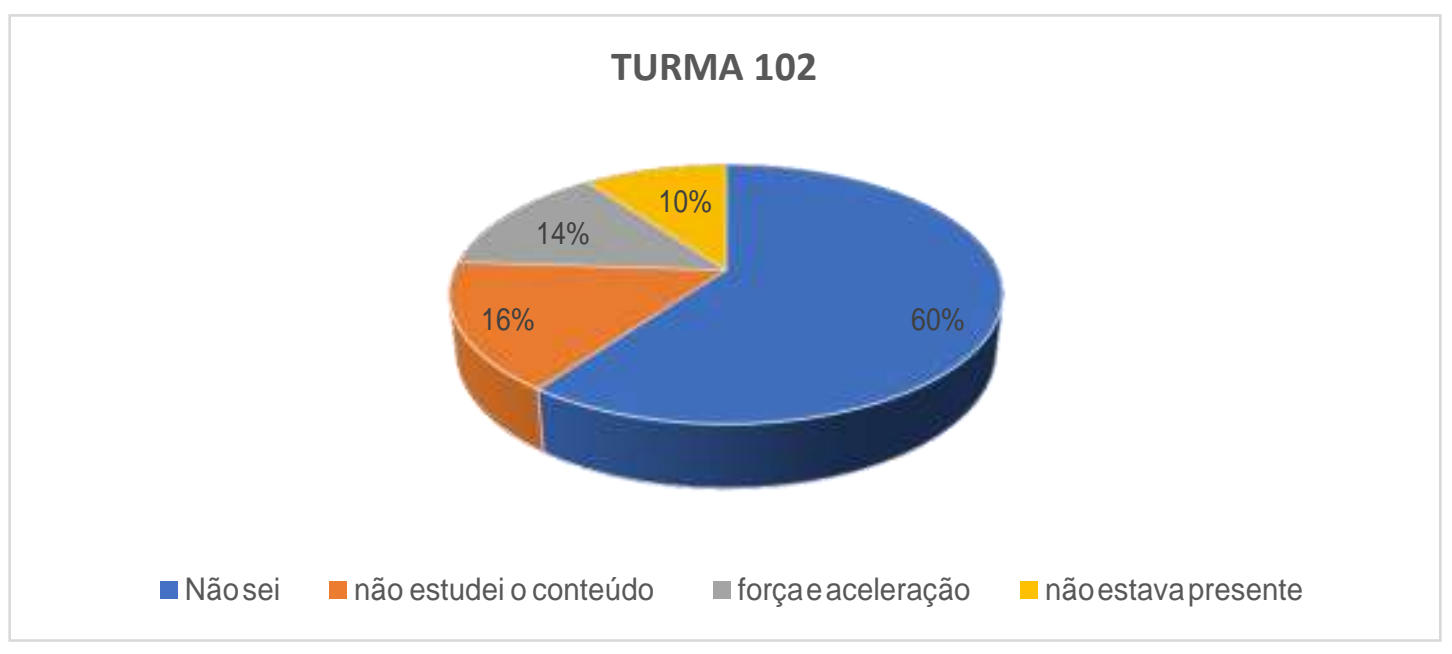

Fonte: Autores (2018).

Diante do exposto acima, é notório que segunda Lei de Newton, ainda que seja um assunto que pareça simples e se faça bastante presente no cotidiano do ser humano em geral, os alunos participantes da pesquisa de ambas as turmas ainda encontram muitas dificuldades em aprender a respeito.

O segundo contato com os alunos foi a partir da aplicação de um questionário que dispôs de questões (que se encontra em anexo) simples sobre o tema, questões essas relacionadas à experiências praticadas no dia a dia dos alunos para verificar o nível de aprendizagem desses alunos em relação à segunda Lei de Newton

$\mathrm{Na}$ turma 101, eles se mostraram mais interessados em aprender sobre o conteúdo, apontando questionamentos, dúvidas e crenças a respeito do tema, mostrando ainda um grande interesse em participar da pesquisa. Já na turma 102, os alunos não mostraram tanto interesse em saber sobre o tema, poucos alunos tiveram dúvidas, muitos deixaram questões em branco, por não saber responder, ter dificuldades e não ter interesse em perguntar. Muitos ainda por receio de perguntar com vergonha dos próprios colegas, isso foi o que deixaram transparecer. Em ambas as turmas foi necessário fazer uma revisão sobre o assunto depois do questionário, justamente porque os alunos tiveram muita dificuldade em responder o questionário.

Na turma 101, o resultado do questionário teve foi razoavelmente positivo, grande parte dos alunos marcaram as alternativas corretas sobre o tema em questão, mas tiveram dificuldades em responder a questão subjetiva. Porém na turma 102, os resultados não foram os melhores, pois a grande maioria dos alunos erraram a maioria das questões objetivas, e, portanto, não responderam a única questão subjetiva.As salas foram organizadas em filas, já que as turmas têm um grande número de alunos.

A forma como as salas foram organizadas encontra-se exposta abaixo: 
Figura 1: organização dos alunos da turma 101.

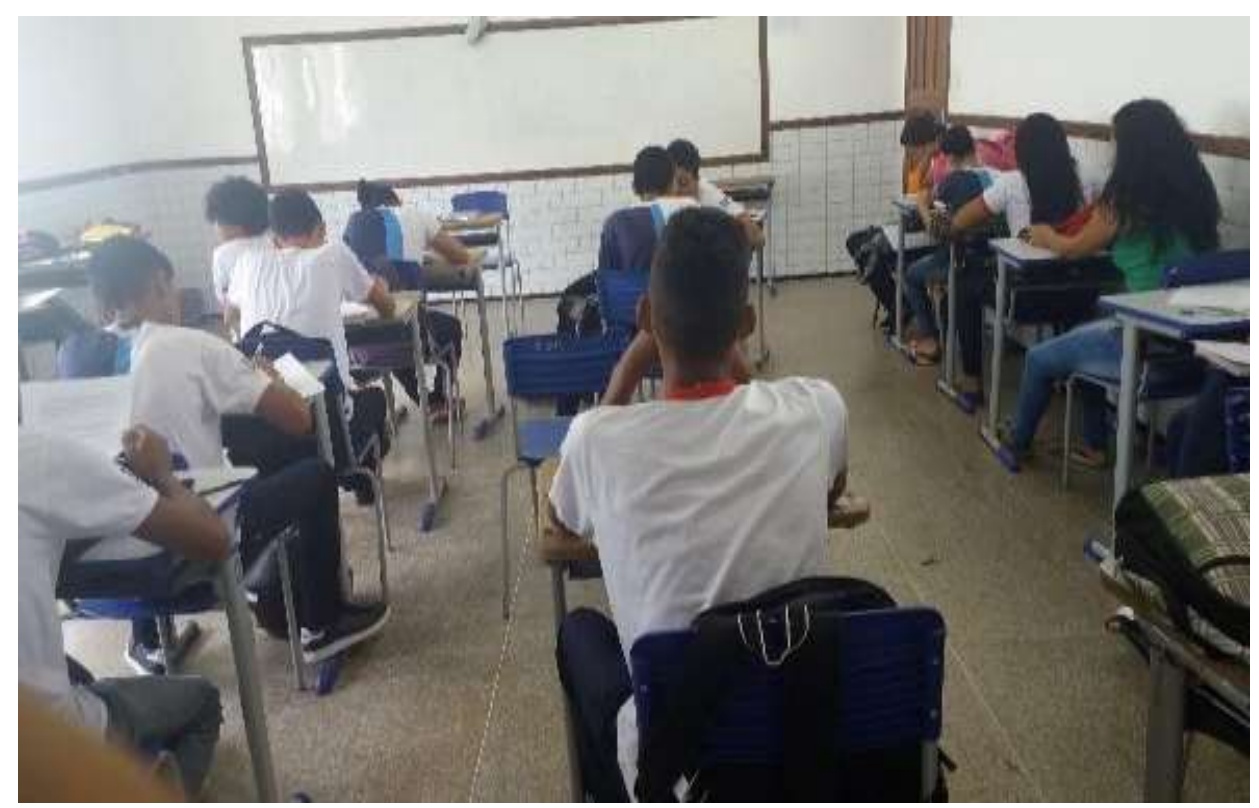

Fonte: Autores (2018) (turma 101).

Figura 2: organização dos alunos da turma 102.

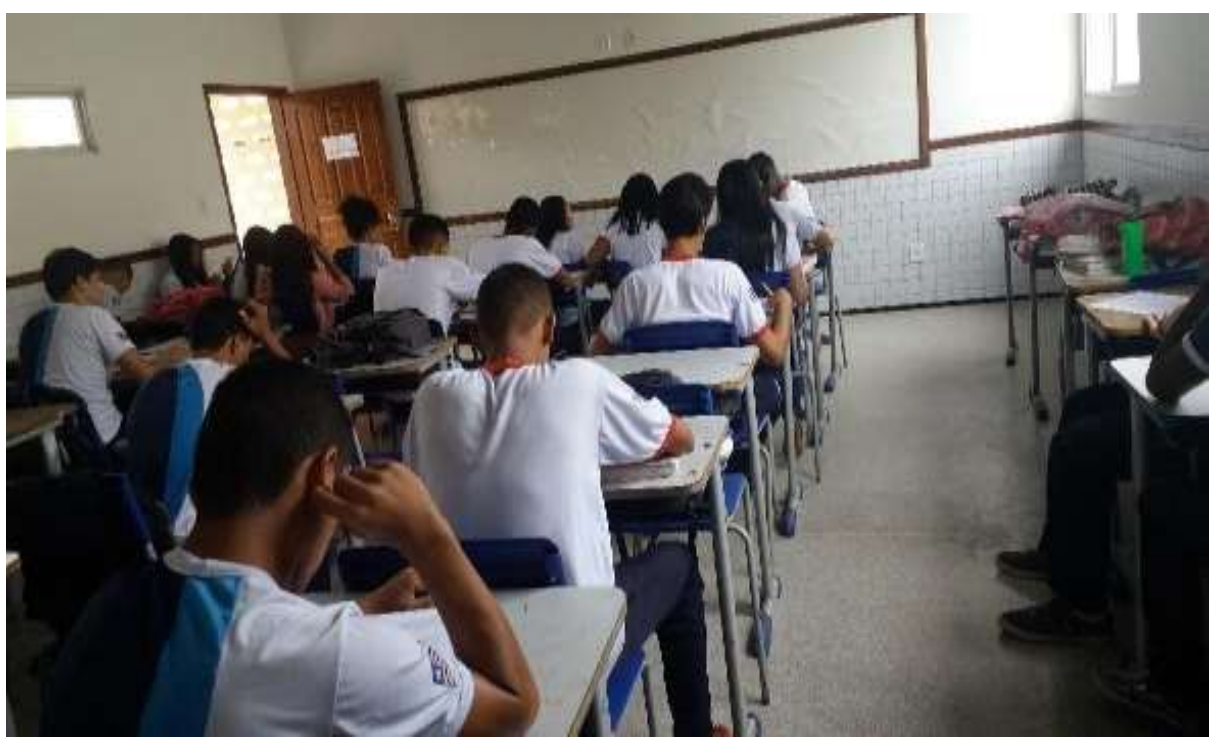

Fonte: Autores (2018) (turma 102).

\section{Na turma 102:}

Depois de observar cada um dos questionários respondidos, foi possível perceber que são muitas as dificuldades dos alunos não só quanto ao tema, mas com relação à disciplina de física no geral. Muitos nem ariscaram em marcar as alternativas, por não saberem o que marcar, durante a aplicação do questionário, vários alunos se manifestaram, afirmando que não sabiam o significado de muitas das palavras ali contidas, embora o mesmo contivesse apenas questões simples, palavras simples e comuns que fazem parte do cotidiano do ser humano em geral. As maiores dificuldades encontradas foram com relação à aceleração, força e movimento. Muitos confundiram a segunda Lei de Newton com a terceira Lei de Newton, isto é, 
com a Lei da ação e reação. Como a dificuldade da turma era muito grande, foi necessário explicar um pouco sobre o conteúdo durante 20 minutos através de situações vivenciadas no cotidiano, ainda que esse não fosse o intuito da pesquisa. Só a partir da explicação feita, foi que eles começaram a pensar e marcar as questões que melhor descrevessem suas experiências, presentes no questionário.

\section{Na turma 101:}

Após as observações feitas nas respostas do primeiro questionário aplicado na turma 101, pôde-se constatar que esta tem um certo nível de dificuldade na disciplina, e principalmente quanto ao conteúdo, porém alguns alunos apresentam um desenvolvimento mais avançado, ou seja, com um conhecimento mais elevado no que diz respeito à disciplina, talvez por terem mais afinidade ou até ter gosto pela disciplina. A faixa etária de idades (essa foi a primeira pergunta que constou no primeiro questionário aplicado nas duas turmas) nessa turma (101), varia de 15 a 17 anos. Abaixo serão apresentadas em forma de gráfico, no qual conterá as porcentagens quanto ao conhecimento dos alunos com relação a segunda Lei de Newton, e a física como um todo.

A segunda pergunta questionava se os alunos já tinham vivenciado ou praticado experiências cotidianas que podiam ser explicadas por meio da segunda Lei de Newton. como resultado foi possível constatar que:

$\checkmark$ A segunda pergunta questionava se os alunos já tinham vivenciado ou praticado experiências cotidianas que podiam ser explicadas por meio da segunda Lei de Newton. como resultado foi possível constatar que:

Gráfico 3: Convivências e experiências dos alunos com a segunda Lei de Newton.

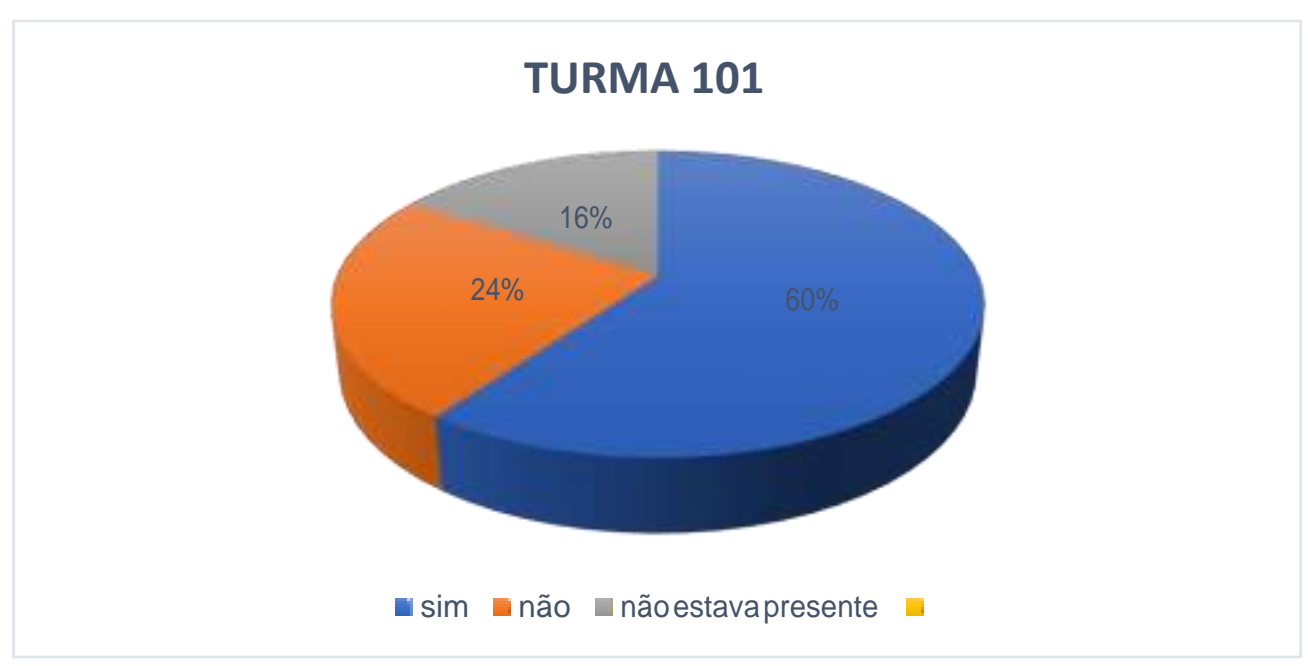

Fonte: Autores (2018).

Percebe-se que se trata da maioria dos alunos que tiveram uma resposta afirmativa sobre tal questão, porém, ainda sim, sentiram dificuldades em destacar, identificar em que momento, em quais ocasiões e situações o fenômeno se fez presente, a justificativa quanto a isso foi que colocaram sim como resposta, porque o que eles entenderam da física até hoje foi que ela faz parte da vida do ser humano.

A terceira questão do questionário, perguntava o seguinte: “Um corpo sob a ação de uma única força obtém uma aceleração de mesma direção e sentido desta? O efeito dessa força sobre o corpo é chamado aceleração? O princípio 
ao qual o referido enunciado se refere é? Os resultados obtidos serão representados graficamente a seguir:

Gráfico 4: Identificação do enunciado da segunda Lei de Newton.

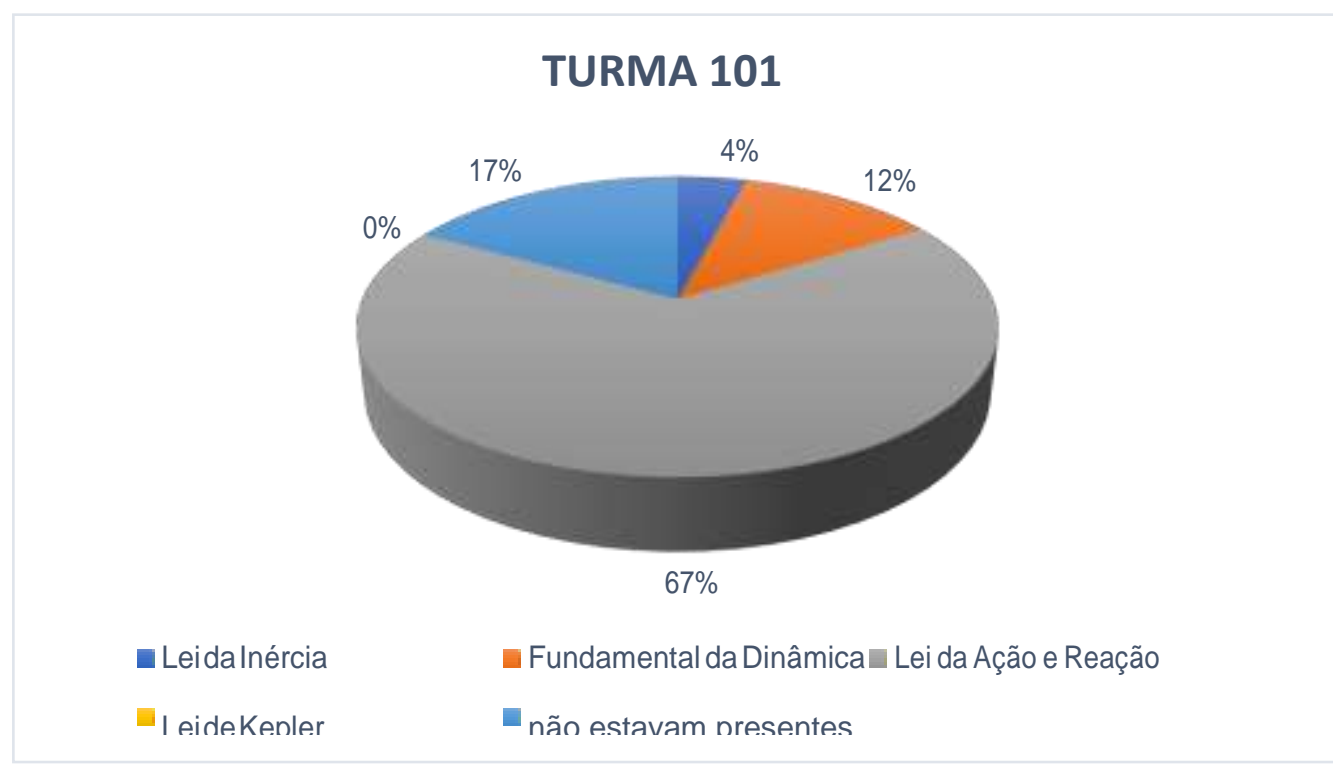

Fonte: Autores (2018).

Pode-se perceber que foram quase que a minoria dos alunos que consideraram a resposta correta, isso confirma o nível de dificuldade que os alunos têm na disciplina embora seja nos conteúdos que se fazem presentes no seu dia a dia, com é o caso da segunda Lei de Newton.

A quarta pergunta teve o seguinte questionamento: "das afirmativas abaixo, marque a(as) que se refere(em) à segunda Lei de Newton.

Com relação a pergunta acima, obteve-se que $0 \%$ dos alunos responderam as alternativas corretas. Nesse caso:

Gráfico 5: Identificação da segunda Lei de Newton.

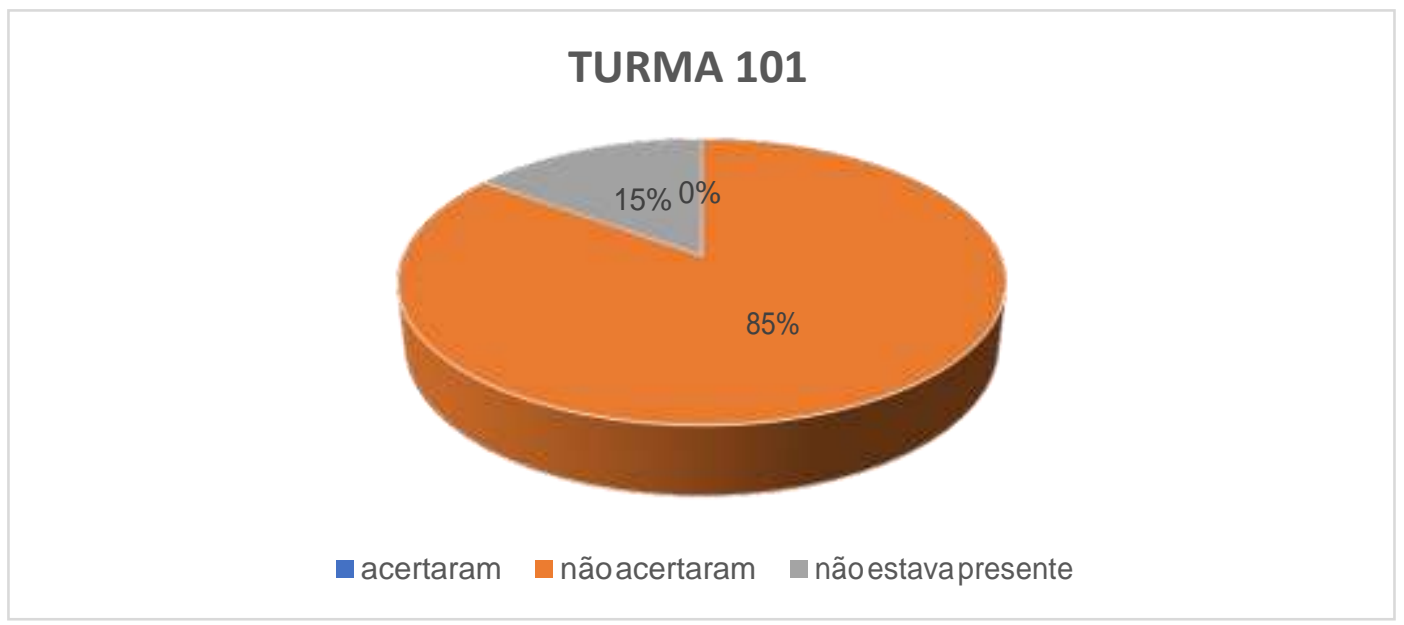

Fonte: Autores (2018). 
$\checkmark$ A quinta questão: “durante o seu percurso de ensino médio, você acredita que aprendeu o necessário sobre a segunda Lei de Newton?"

Representando graficamente tem-se:

Gráfico 6: valores com o nível de aprendizado dos alunos sobre a segunda Lei de Newton.

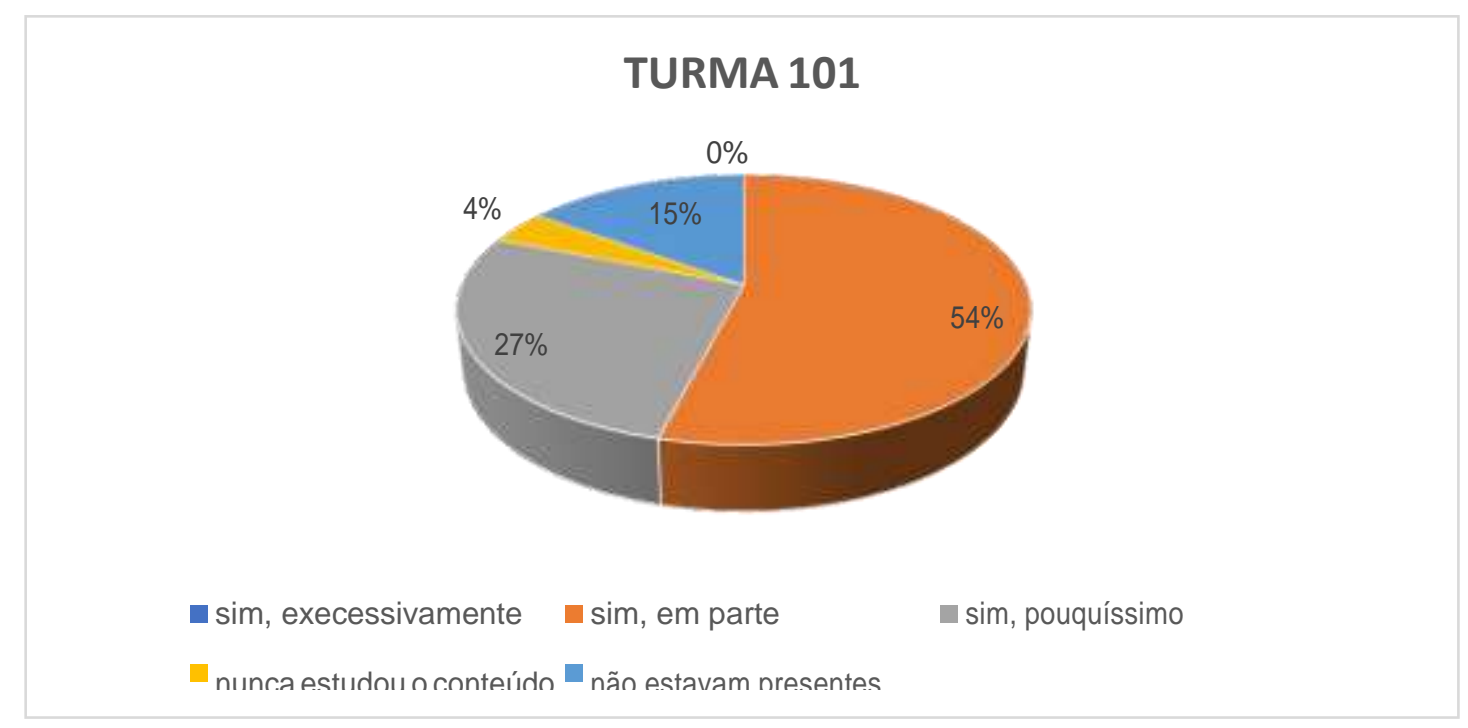

Fonte: Autores (2018).

Percebe-se que a maioria dos alunos afirmaram ter aprendido o necessário quanto a segunda Lei de Newton, depois de serem observados e identificados esse índice tão alto quanto a aprendizagem dos mesmos, na aula seguinte, foi então feita uma discussão na sala quanto a essa pergunta, no entanto, eles consideraram que aprenderam apenas com o exemplo dado sobre o carrinho de supermercado, mas que tinham um maior interesse em se aprofundar no conteúdo.

$\checkmark$ Questão seguinte: sobre a segunda Lei de Newton, é correto afirmar que?

como resultado dessa questão, apenas 6 alunos conseguiram acertar a alternativa correta, letra com isso, pode-se perceber que mesmo a segunda Lei de Newton sendo um assunto bastante presente no nosso cotidiano, ainda sim os alunos sentem muita dificuldade em identificar e assimilar tais fenômeno com seu cotidiano.

Como resultado, tem-se: 
Gráfico 7: conhecimento dos alunos quanto a segunda Lei de Newton.

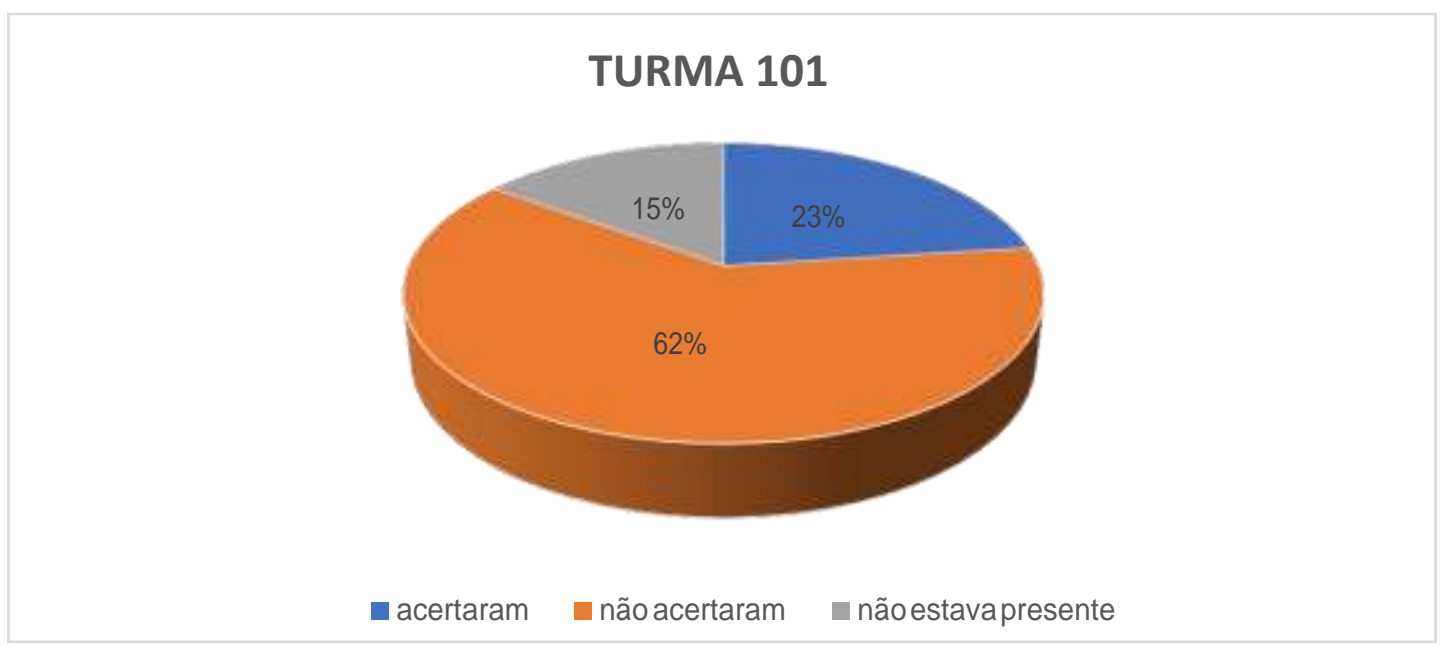

Fonte: Autores (2018).

Depois que concluir o ensino médio, ao prestar vestibular e o mesmo dispor de questões referentes à segunda Lei de Newton, com os conhecimentos prévios adquiridos por você durante o ensino médio, você acha que faria um bom vestibular? Representando graficamente os resultados obtidos com relação à pergunta acima, tem-se que:

Gráfico 8: Possível rendimento dos alunos ao prestar vestibular sobre a segunda Lei de Newton (turma 101).

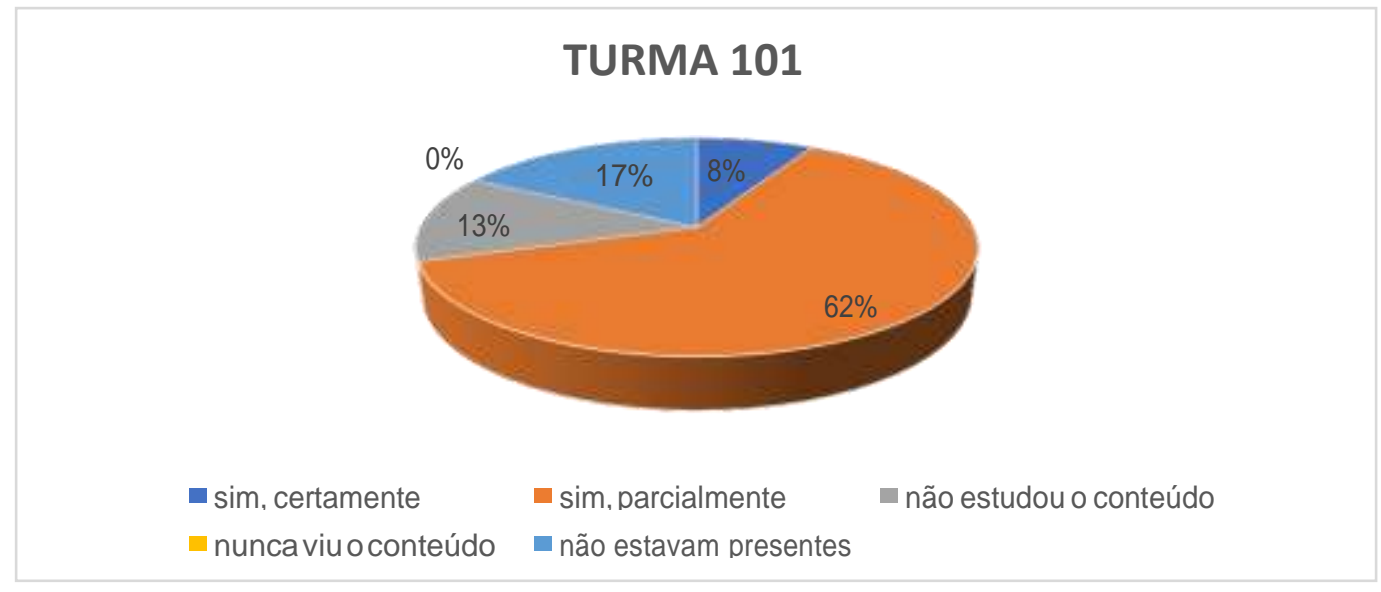

Fonte: Autores (2018).

A oitava questão enuncia o seguinte: você já prestou vestibular que adotou questões relacionadas à segunda Lei de Newton?

A análise da questão acima, dispõe da seguinte representação: 
Gráfico 9: Questões de Vestibular, que abordavam a 2 Lei de Newton.

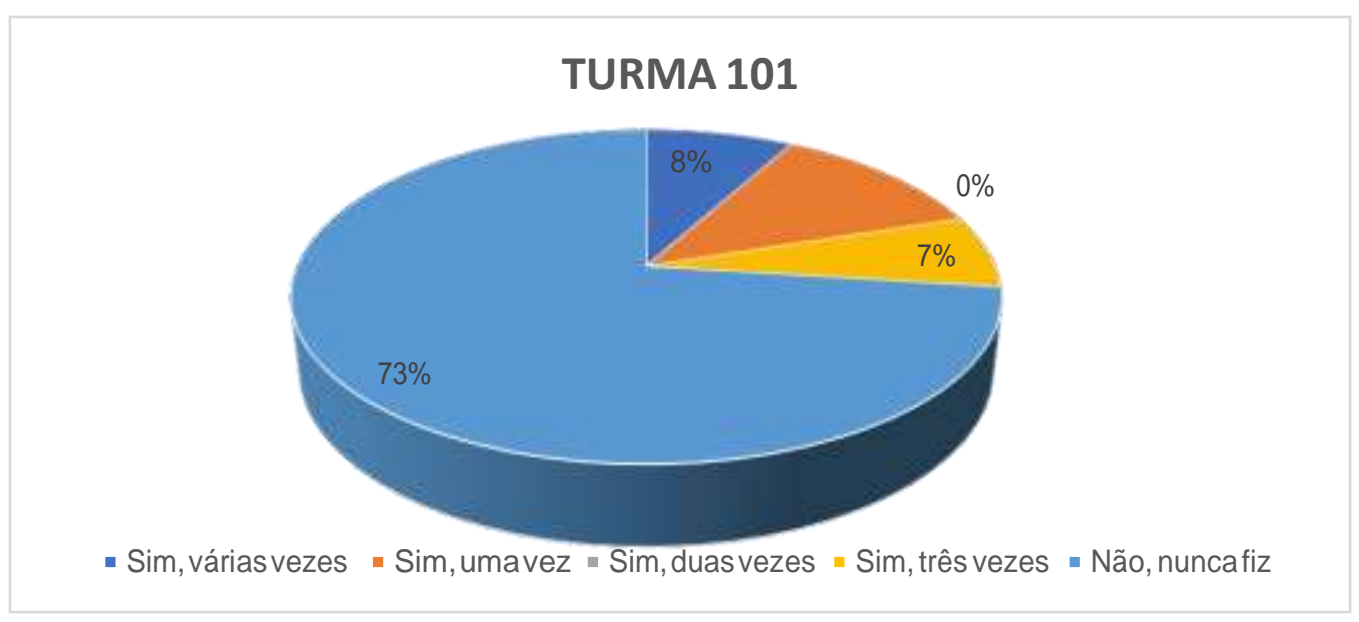

Fonte: Autores (2018).

Com base nos resultados acima, a maioria dos alunos (cerca de $73 \%$ dos discentes) nunca prestaram vestibular onde abordava questões sobre a segunda Lei de Newton, isso faz com que a pesquisa se torne ainda mais interessante, já que os alunos terão um interesse maior em aprender sobre o conteúdo, por se tratar de uma nova experiência metodológica. E nesse caso, $12 \%$ fizeram uma vez, $8 \%$ fizeram várias vezes, $7 \%$ fizeram três vezes e $0 \%$ nunca fez.

A nona questão argumentava que: "Se você tivesse que fazer um texto-dissertativo

$\checkmark$ argumentativo, ao prestar vestibular, em exemplo, o Enem, você acha que faria uma boa dissertação sobre o conteúdo?"

Gráfico 10: rendimento dos alunos ao construir uma possível dissertação sobre a segunda Lei de Newton (Turma 101).

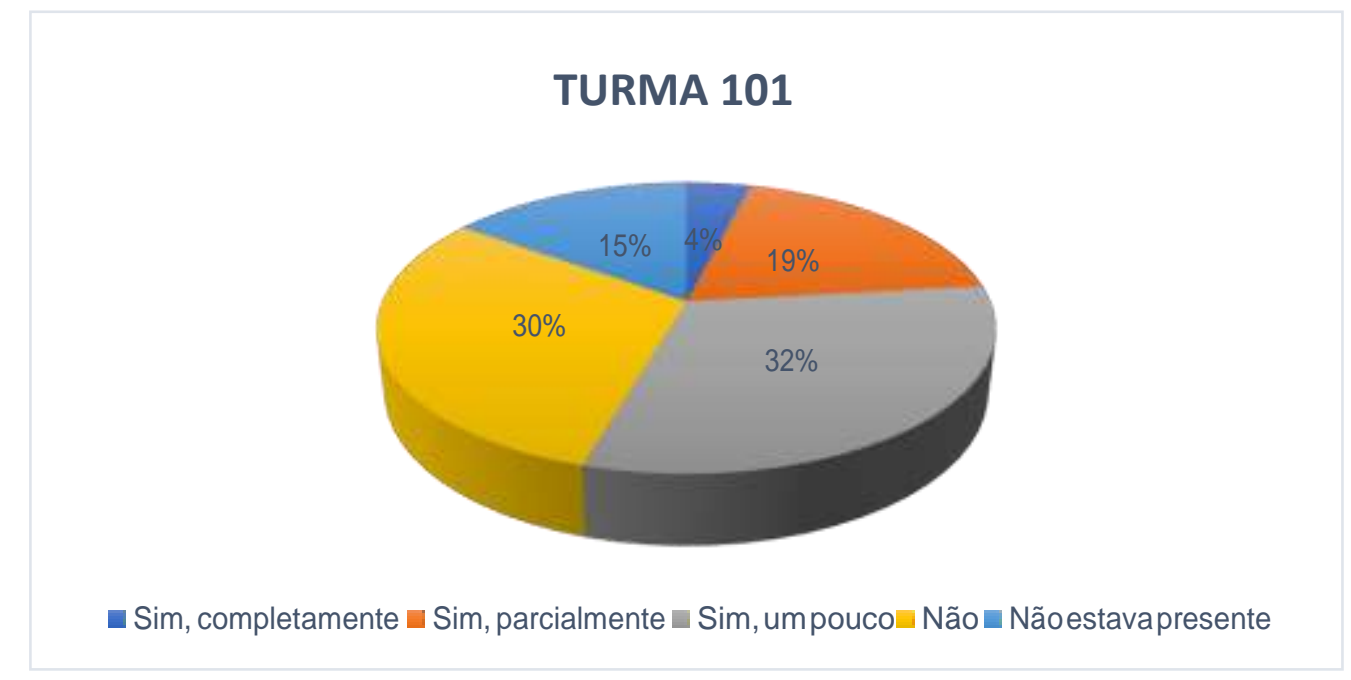

Fonte: Autores (2018). 
A questão seguinte questionava: Você já fez algum trabalho escolar ou alguma pesquisa científica sobre a segunda Lei de Newton?

Como resultado do questionamento acima, tem-se:

Gráfico 11: resultados para pesquisa cientifica sobre a segunda Lei de Newton (turma 101).

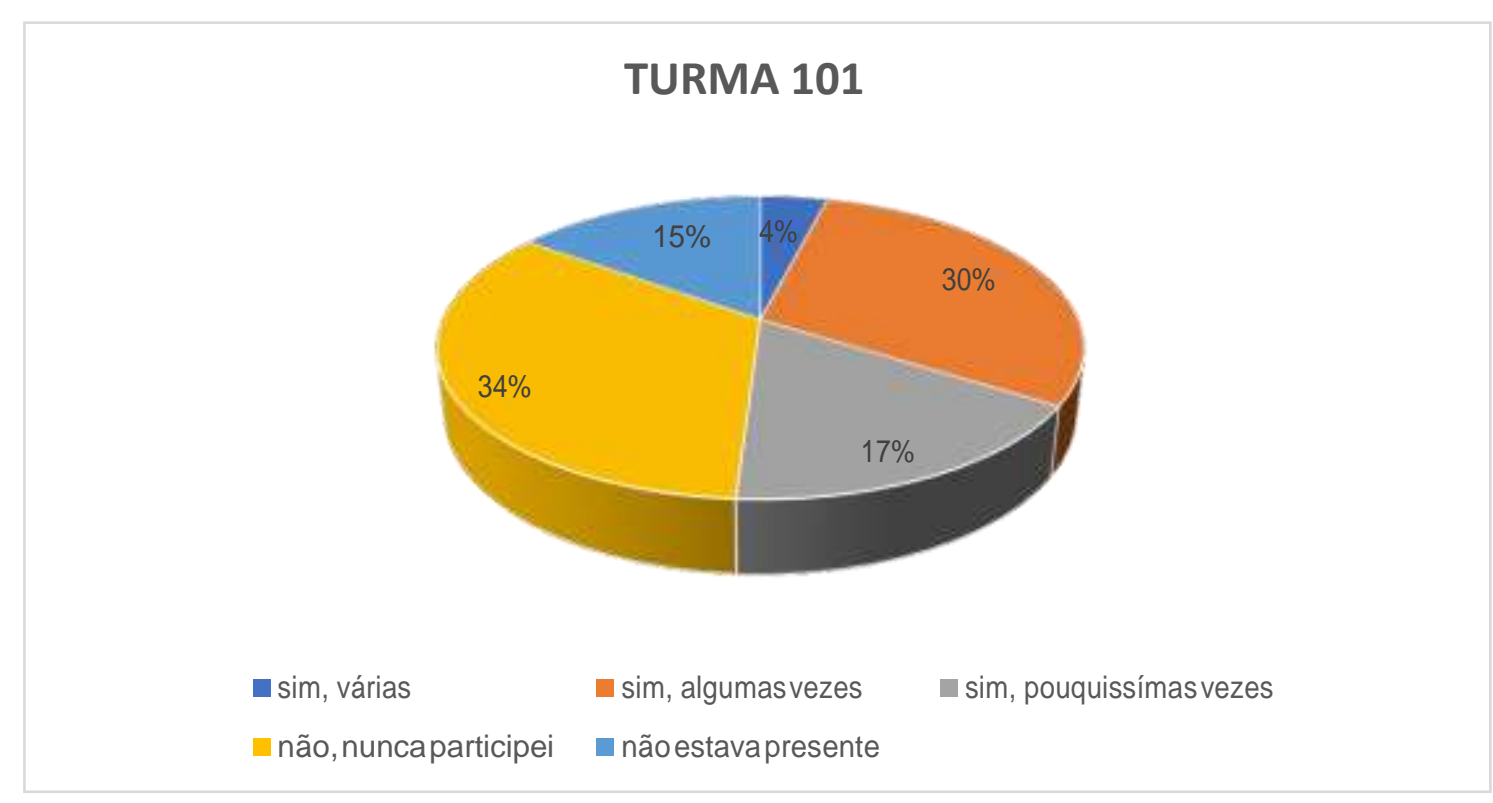

Fonte: Autores (2018).

$\checkmark$ A próxima questão foi de cunho subjetivo, onde os alunos poderiam a partir dos seus conhecimentos prévios, escrever o que entendiam sobre a segunda Lei de Newton. 50\% dos alunos fizeram breves comentários, mas a maioria deles não tiveram argumentos significativos quanto ao assunto, isto é, tiveram respostas vagas a respeito.

Abaixo, estão expostas algumas das respostas dos alunos quanto ao tema da pesquisa: 
Tabela 1 - Relato dos alunos sobre seus conhecimentos prévios com relação a segunda Lei de Newton.

\begin{tabular}{|l|l|}
\hline Aluno W & $\begin{array}{l}\text { "quando uma age sobre este adquire uma aceleração, à } \\
\text { medida que o valor da força aplicada sobre um corpo qualquer for } \\
\text { aumentando, o valor da aceleração". }\end{array}$ \\
\hline Aluno X & $\begin{array}{l}\text { "no caso de um carrinho de supermercado que está parado, mas quando } \\
\text { empurra, ou seja, exerce uma força sobre o } \\
\text { carrinho que entrará em movimento". }\end{array}$ \\
\hline Aluno Y & $\begin{array}{l}\text { "eu entendi que para uma massa entrar em movimento é necessário que } \\
\text { uma força é aplicada sobre ele", }\end{array}$ \\
\hline Aluno Z & "que proporciona uma proporção sobre velocidade e massa. \\
\hline
\end{tabular}

Fonte: Autores (2018).

A penúltima pergunta do questionário teve o seguinte enunciado: Durante sua trajetória de ensino médio, você já realizou experimentos que fomentassem sobre a segunda Lei de Newton?

Gráfico 12: realização ou não de experimentos sobre segunda Lei de Newton (turma 101).

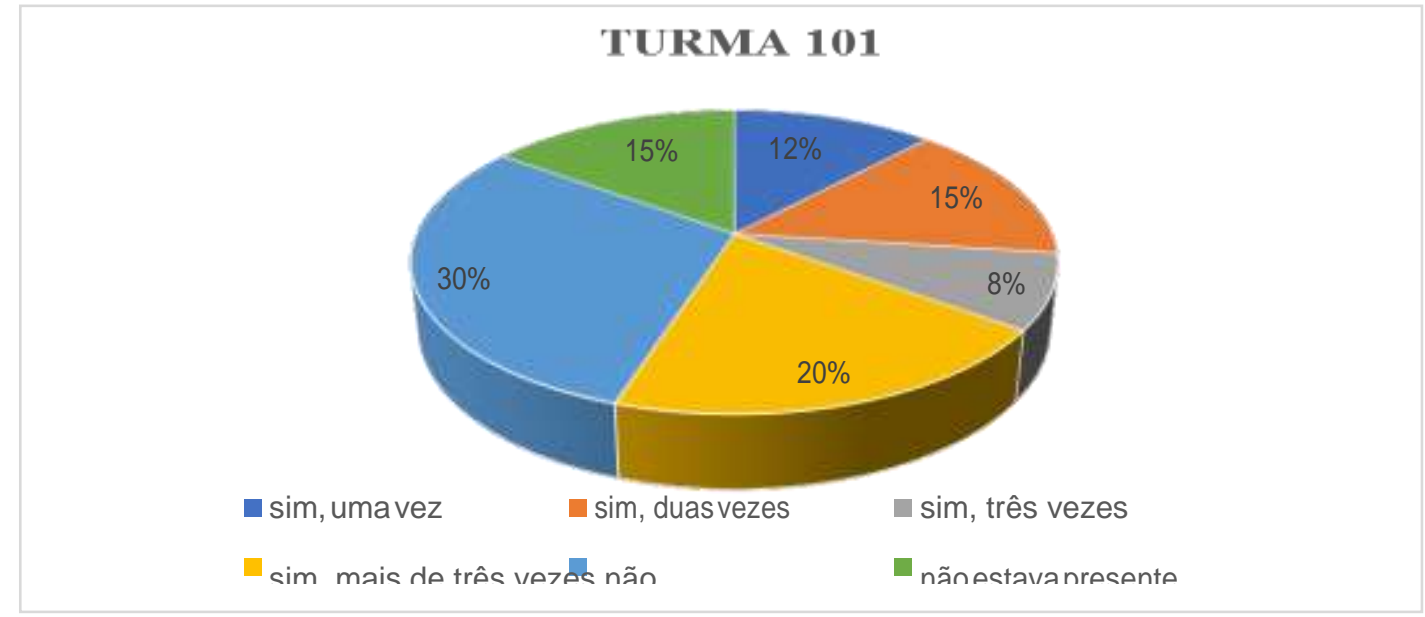

Fonte: Autores (2018).

E finalmente a última pergunta do questionário anunciava que: Você já deve ter tido a experiência de ir ao supermercado e empurrar o carrinho de compra. Então deve ter percebido que para que ele entre em movimento, é necessário que apliquemos uma força sobre ele. Deve ter percebido também que quanto mais pesado o carrinho tiver, isto é, quanto mais mercadorias forem colocadas no carrinho, maior será sua massa e, e consequentemente maior será a força que você terá que exercer sobre este e provocar a mesma aceleração.

Diante do exposto acima, tal fenômeno pode ser explicado através da(o): o resultado para tal pergunta está representado no gráfico abaixo: 
Gráfico 13: existência ou não de experiência com a segunda Lei de Newton no cotidiano dos alunos.

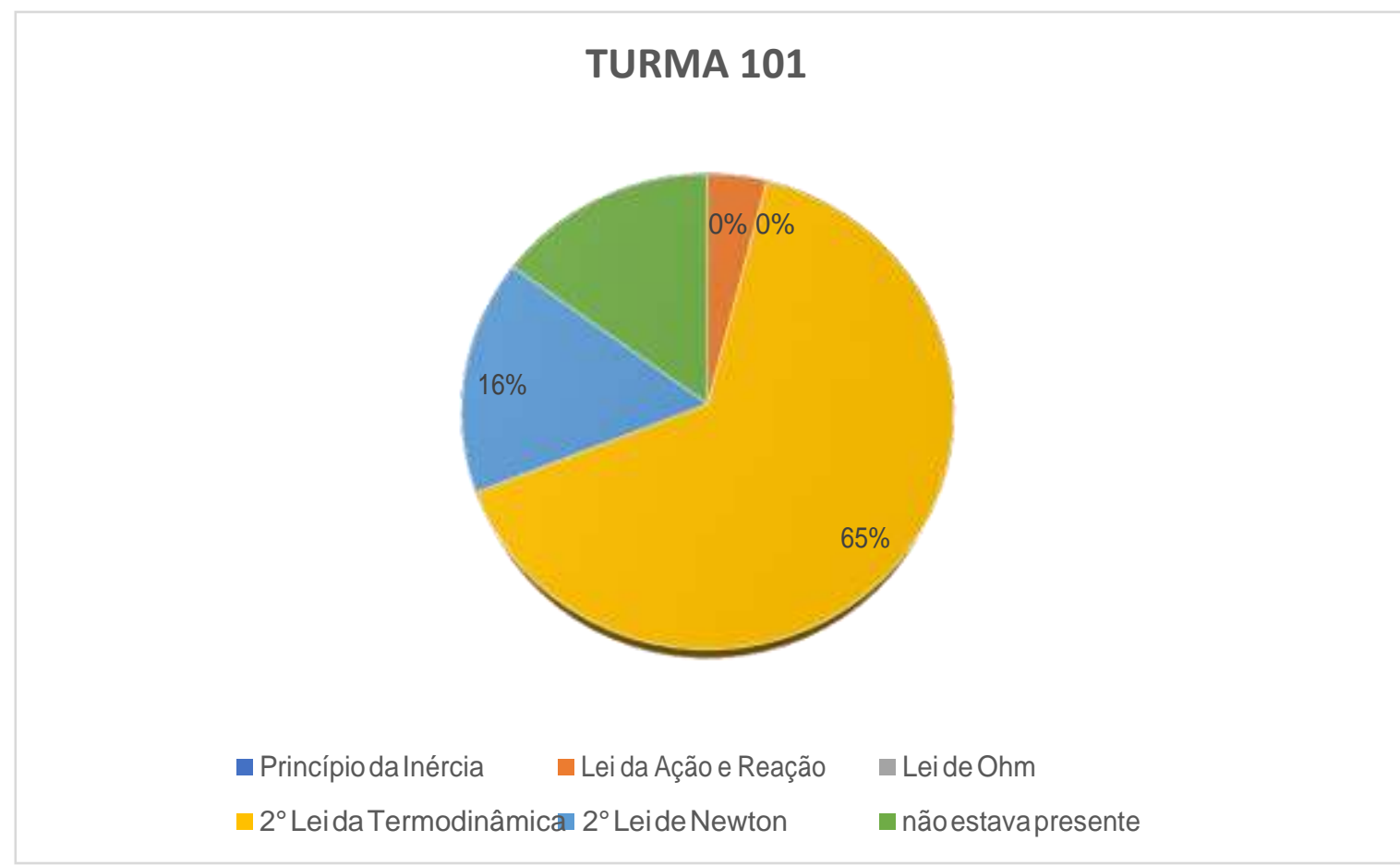

Fonte: Autores (2018).

Gráfico 14: convivências e experiências dos alunos com a Mecânica Newtoniana.

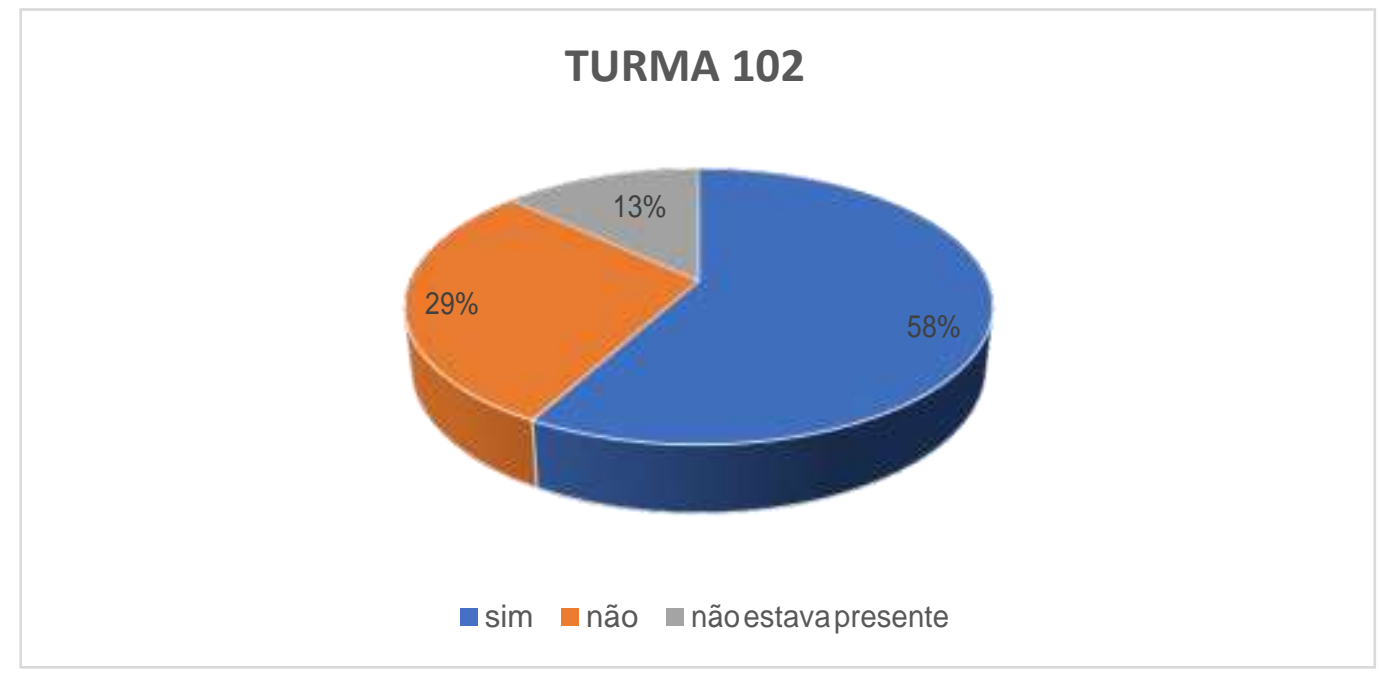

Fonte: Autores (2018).

Com base nos resultados acima, pode-se perceber que a maioria dos alunos confundiram a segunda Lei de Newton com a segunda Lei da Termodinâmica, depois da aplicação do questionário foi-se perguntado porque eles tinham marcado a segunda Lei da Termodinâmica ao invés d segunda Lei de Newton, a maioria dos alunos pensavam que se tratava do mesmo conteúdo, e também por não terem conhecimento suficiente com relação ao tema da pesquisa em questão (segunda Lei de Newton: teoria versus aplicação no cotidiano). 
A próxima análise foi feita com a turma 102, também de $1^{\circ}$ ano (primeiro ano). O questionário aplicado na turma 102, foi o mesmo aplicado na turma 102. E os resultados deste também será representado graficamente, logo abaixo:

As perguntas do questionário foram descritas acima, nos resultados da turma 101, com isso será representado apenas os resultados da turma 102. A turma tem um número maior de alunos, totalizando um em torno de 38 alunos matriculados, porém houve 5 faltosos nesse primeiro encontro, e com isso, a pesquisa foi feita com 33 alunos. É importante ressaltar que o questionário em questão estará nos anexos finais deste trabalho e que a primeira pergunta era sobre a idade dos alunos, o que já foi esclarecido acima.

Os resultados da segunda questão (lembrando que o mesmo questionário foi aplicado nas duas turmas) foram:

Foi possível notar que praticamente a metade da turma confundiu a terceira Lei de Newton, com a segunda Lei de Newton nessa segunda questão, o que pode ser prejudicial para o desenvolvimento de ambos, principalmente na hora de prestar vestibular que abordem sobre essas questões da mecânica Newton. a seguir tem-se a representação gráfica dos resultados da presente questão:

Gráfico 15: Identificação do enunciado da segunda Lei de Newton.

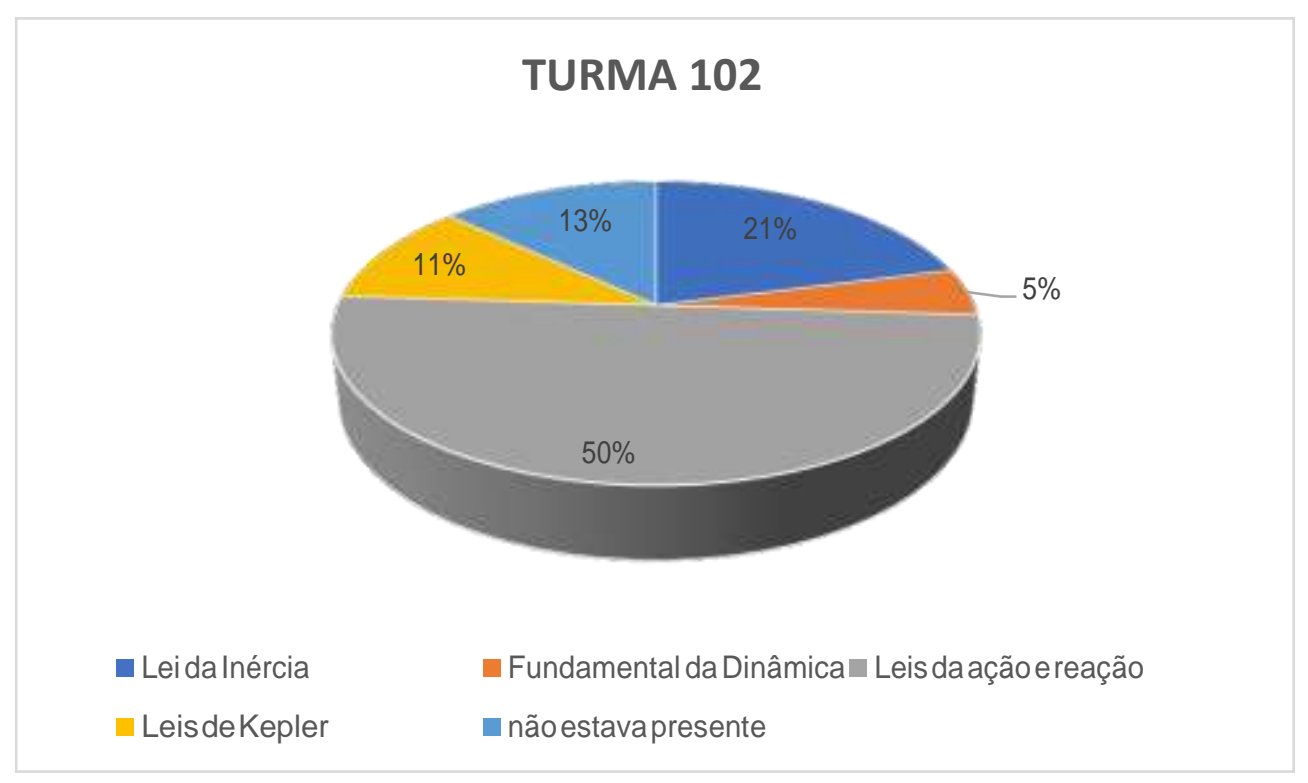

Fonte: Autores (2018). 


\section{$\checkmark \quad$ Quarta pergunta:}

Gráfico 16: nomenclatura da segunda Lei de Newton.

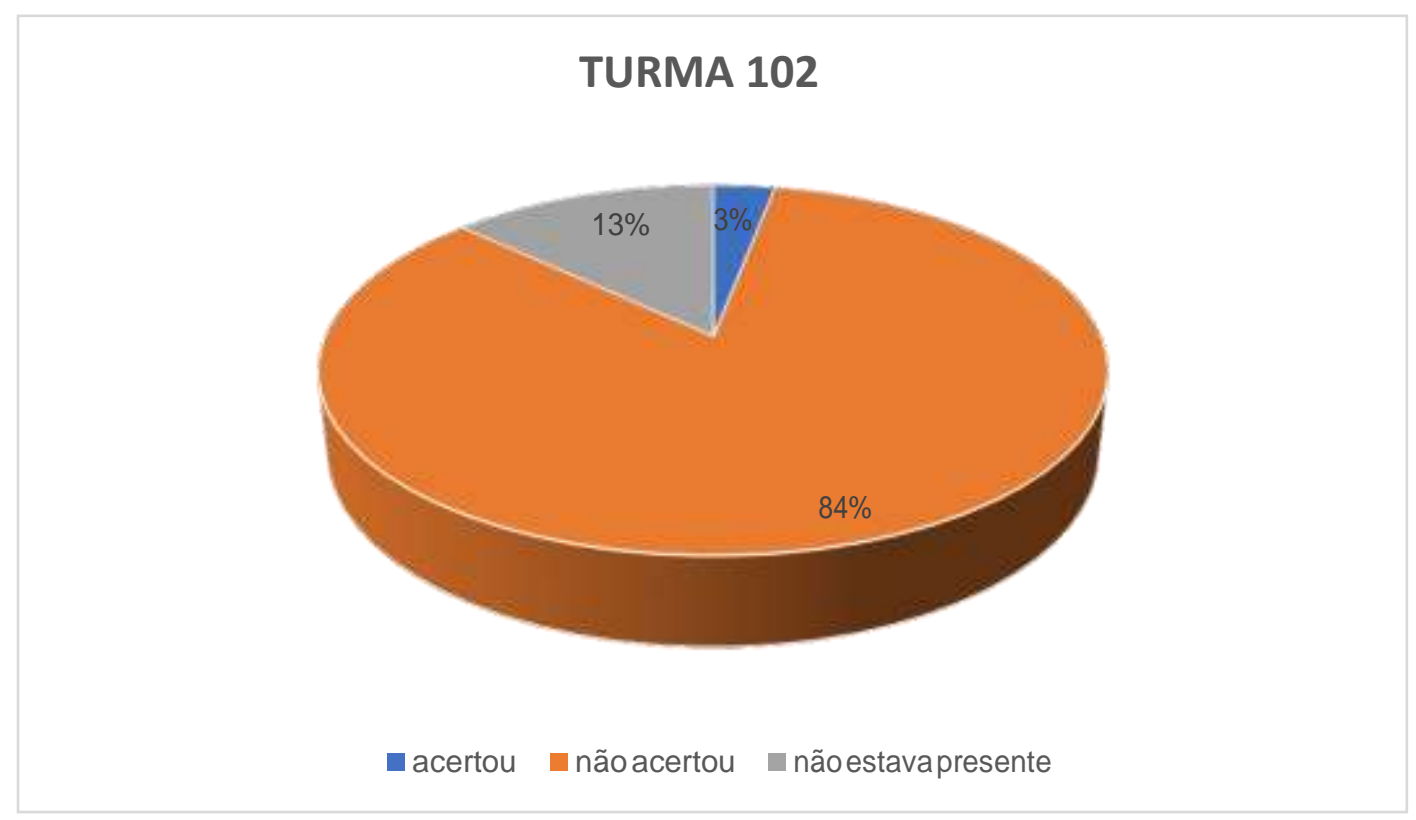

Fonte: Autores (2018).

Gráfico 17: nível dos conhecimentos prévios dos alunos sobre a segunda Lei de Newton.

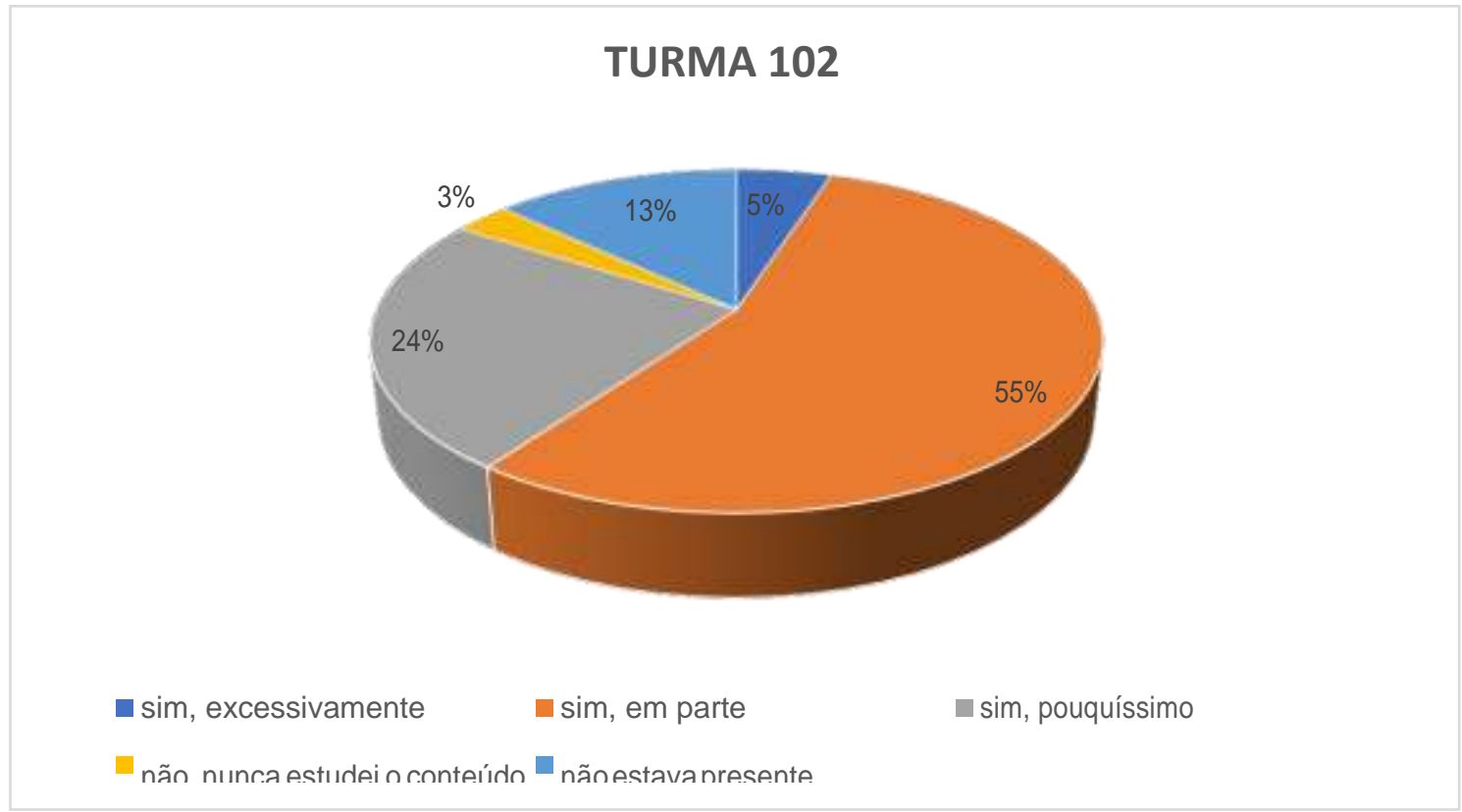

Fonte: Autores (2018).

Com base nos resultados da representação acima, pode-se perceber que pelos menos metade da turma já viu bastante o conteúdo em questão. mas é importante ressaltar que apesar de termos esse número grande de alunos que já viram o conteúdo, a maioria deles resolveram comentar que este foi visto sim na sala de aula, mas apenas como mais um conteúdo da física, e não 
como um dos possíveis elos a chamar atenção para o interesse dos alunos pela disciplina. Com isso, mostraram interesse em embarcar na experiência proposta que foi a pesquisa em questão, ao qual trazia uma nova metodologia de ensino para os educandos e para os professores.

$\checkmark$ Sexta questão:

Gráfico 18: Identificação do enunciado da segunda Lei de Newton.

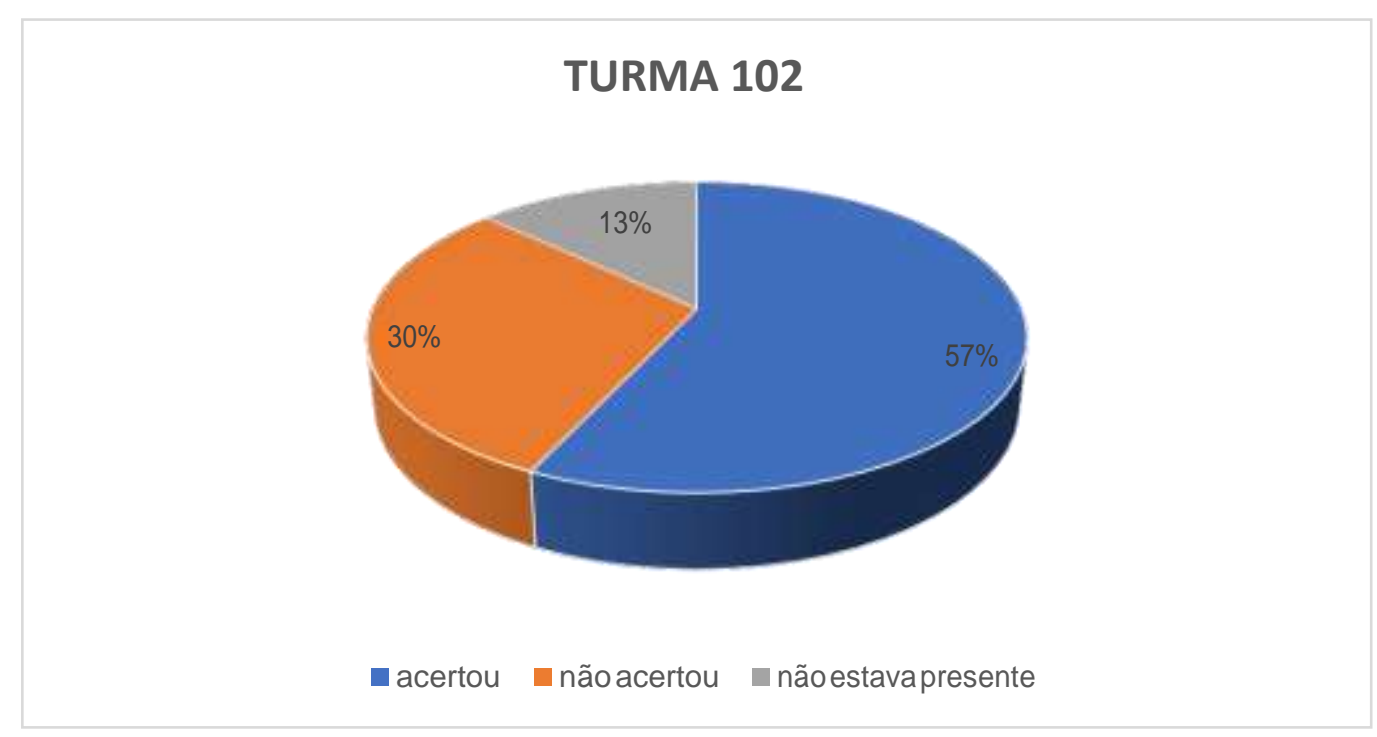

Fonte: Autores (2018).

Baseando-se nos resultados expostos acima, que os alunos realmente já têm uma noção do que se trata a segunda lei de Newton, ainda que seja de forma vaga, sabem que a resultante das forças aplicada a um corpo é igual ao produto da massa por sua aceleração.

A sétima questão:

Gráfico 19: rendimento dos alunos ao prestar vestibular sobre a $2^{\mathrm{a}}$ Lei de Newton.

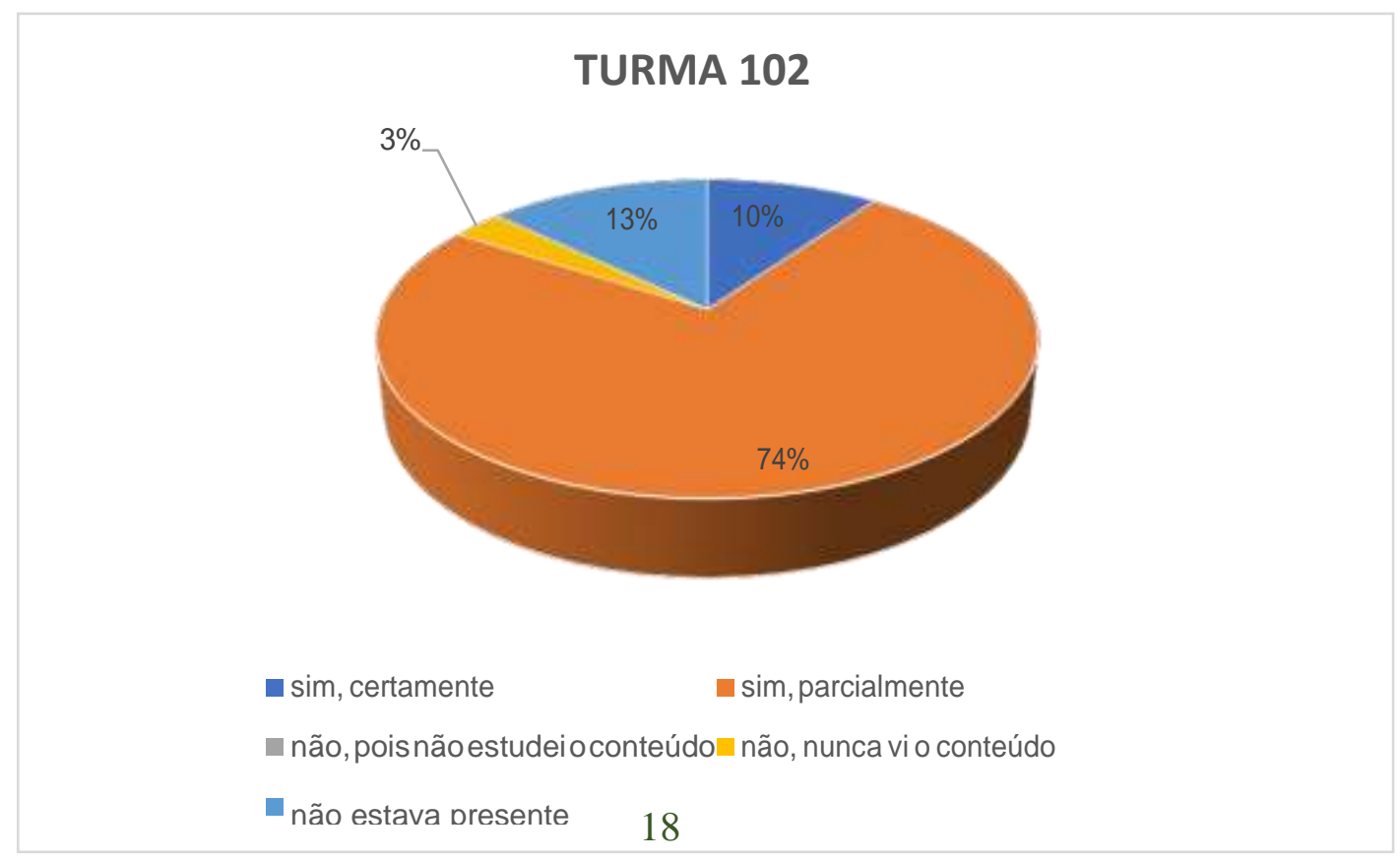


Research, Society and Development, v. 10, n. 2, e1321025727, 2021

(CC BY 4.0) | ISSN 2525-3409 | DOI: http://dx.doi.org/10.33448/rsd-v10i1.5727

Fonte: Autores (2018).

Gráfico da oitava questão:

Gráfico 20: Prestação ou não de vestibulares sobre a segunda Lei de Newton.

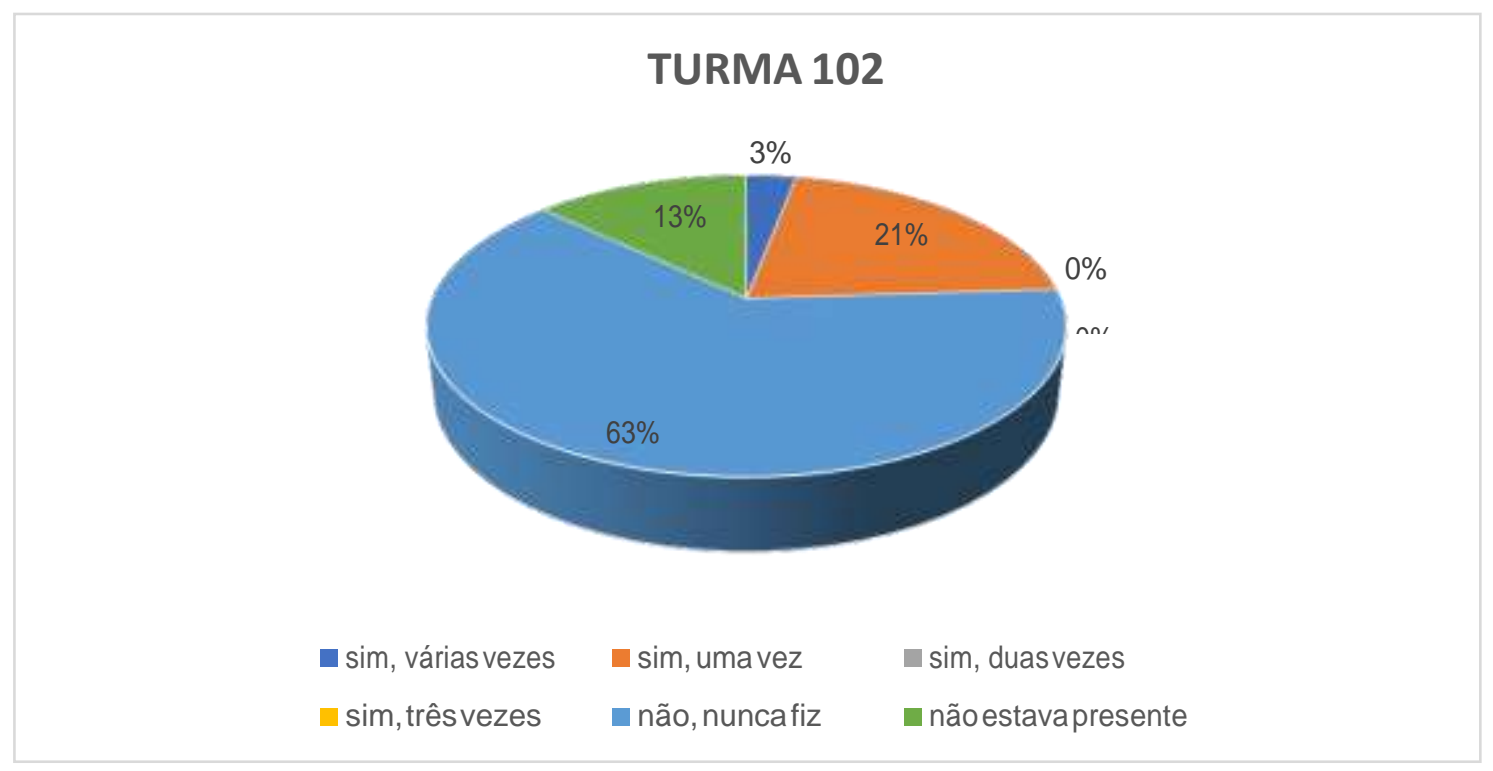

Fonte: Autores (2018).

Resultados para a nona questão:

Gráfico 21: rendimento dos alunos ao construir uma possível dissertação sobre a segunda Lei de Newton.

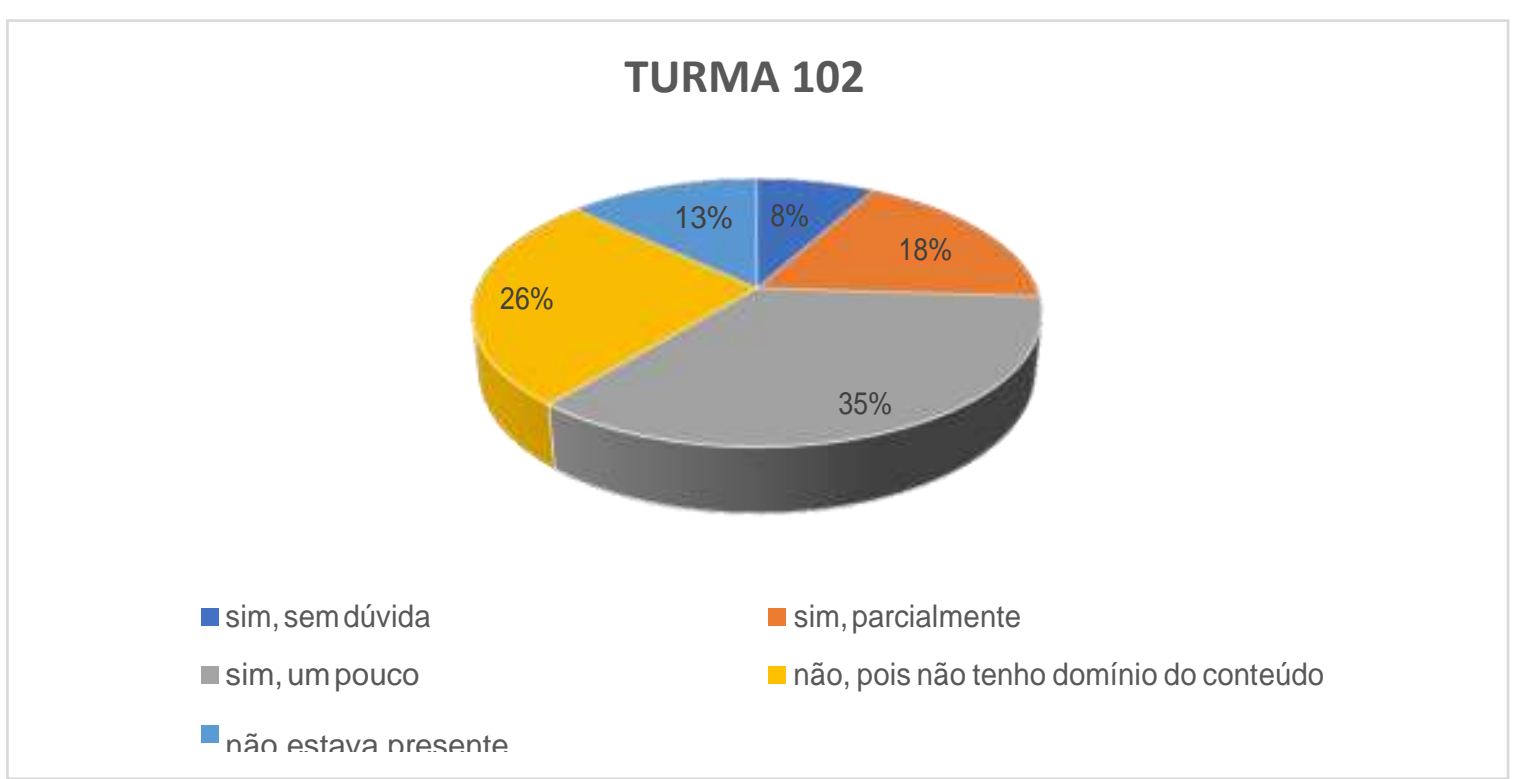

Fonte: Autores (2018). 
Resultados para a décima questão:

Gráfico 22: realização ou não de pesquisa científica sobre a segunda Lei de Newton.

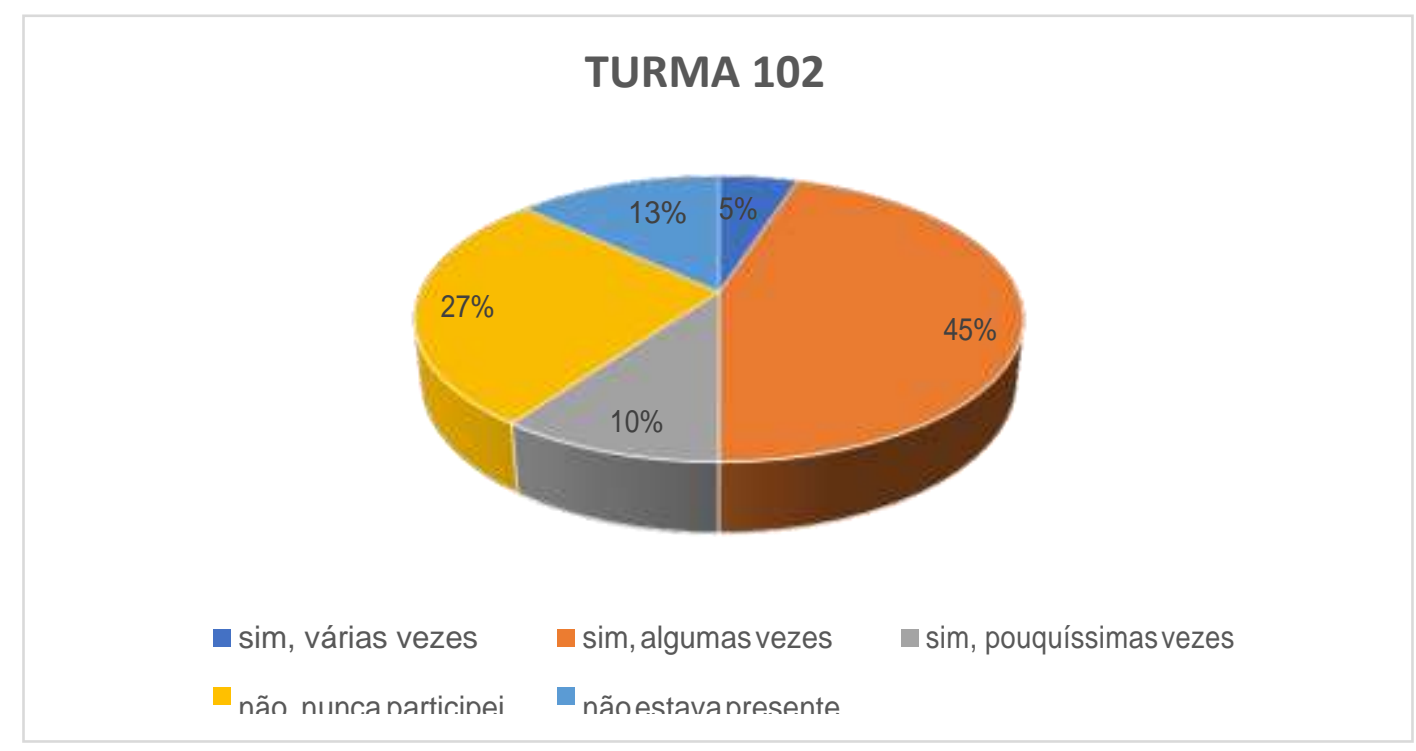

Fonte: Autores (2018).

Como já foi informado nos resultados da turma 101, a décima primeira questão foi a única questão discursiva do primeiro questionário, e pedia para os discentes fazer um breve comentário sobre o que entendem por segunda Lei de Newton, porém não se teve um bom resultado, pois a maioria da turma não soube se expressar e boa parte deles deixaram a questão em branco. E os poucos que ainda argumentaram algo a respeito, fizeram comentários vagos e até incoerentes. Segue abaixo alguns dos comentários feitos pelos alunos com relação à pergunta:

\begin{tabular}{|l|l|}
\hline \multicolumn{2}{|l|}{ Tabela 2 - conceito dos alunos sobre a segunda Lei de Newton. } \\
\hline Aluno A & $\begin{array}{l}\text { "A força que exerce sobre um corpo é o } \\
\text { movimento". }\end{array}$ \\
\hline Aluno B & "Toda ação tem sua reação" \\
\hline Aluno C & $\begin{array}{l}\text { "Que a força aplicada é igual a massa do } \\
\text { mesmo vezes a sua aceleração". }\end{array}$ \\
\hline Aluno D & $\begin{array}{l}\text { "Que para um corpo se mover temos que } \\
\text { aplicar uma força sobre ele, e quanto, maior a massa, } \\
\text { mais força deve ser exercida". }\end{array}$ \\
\hline
\end{tabular}

Fonte: Autores (2018).

Com base nas informações da tabela acima, pode-se perceber que os alunos quando não confundem a segunda Lei de Newton, com a terceira Lei também de Newton, acabam não tendo o domínio de formar frases, discutir e ter opiniões próprias com relação ao conteúdo, o que pode ser um grande fator prejudicial aos educandos. 
$\checkmark$ Resultados para a décima segunda questão:

Gráfico 23: Realização de experimentos sobre a segunda Lei de Newton.

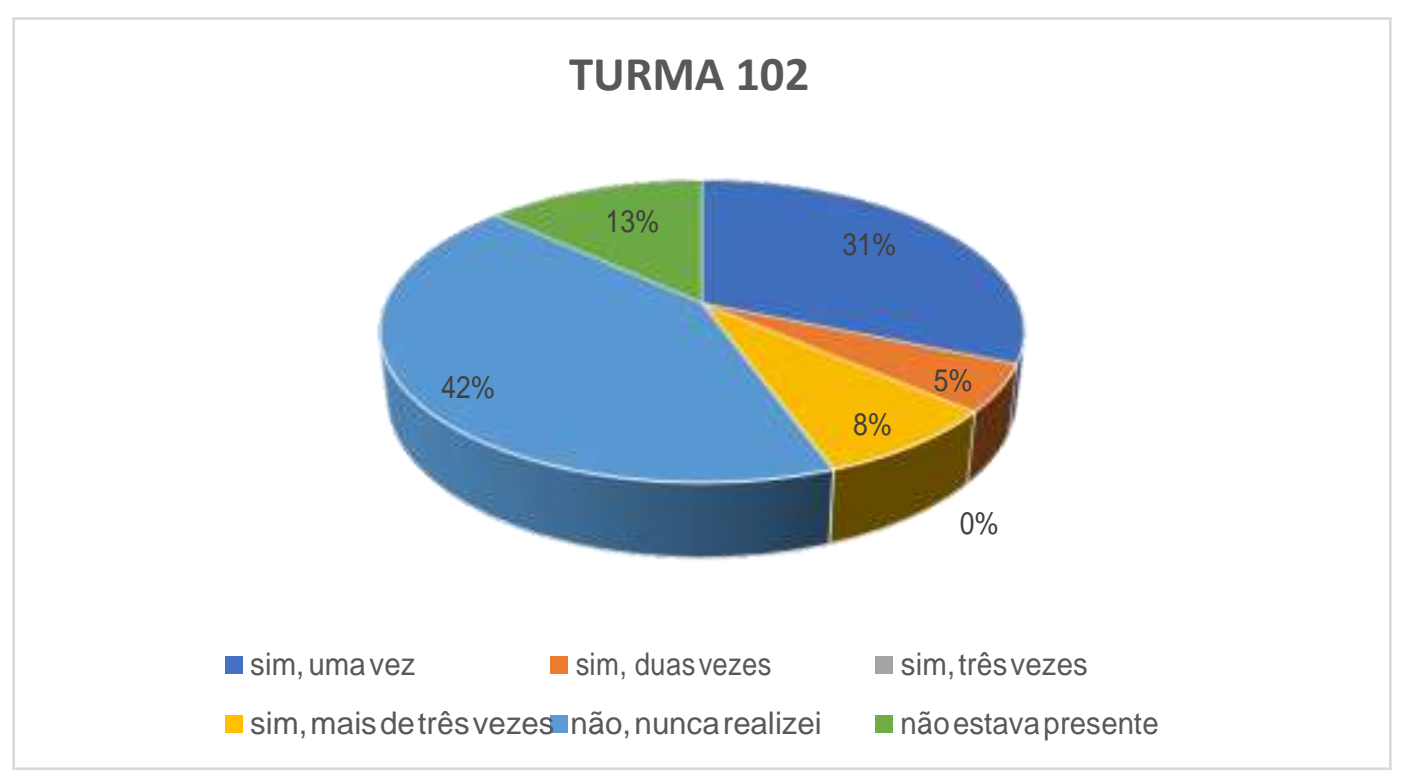

Fonte: Autores (2018).

1. Sim (uma vez): $31 \%$ dos discentes.

Percebe-se, que a maioria dos alunos nunca realizaram experimentos sobre a segunda a segunda Lei de Newton, afirmaram ainda, por meio de discursos, que a aula de física é sempre chata porque sempre é a mesma coisa, copiar o que o professor escreve na frente (na lousa), afirmaram ainda: “ professora, a gente nem tem como gostar de física porque o que sempre vemos é: o professor escreve e a gente e copia o que está escrito no quadro, isso é chato", “a física já é difícil e ainda sendo vista sempre a mesma coisa, o mesmo jeito de aprender a copiar, desde quando minha mãe estudava, era assim, por isso não gosto dessa disciplina”, “ não entendo, se a física faz parte da nossa vida, porque não somos ensinados a comprovar isso?”. Esse último comentário, foi o que mais chamou atenção, pois se tornaria ainda maior o desafio da presente pesquisa, trazer para os alunos um dos pontos da física que podia fazer com que eles viessem a ter um olhar diferente para a física. 
Gráfico 24: experiências cotidianas sobre a segunda Lei de Newton.

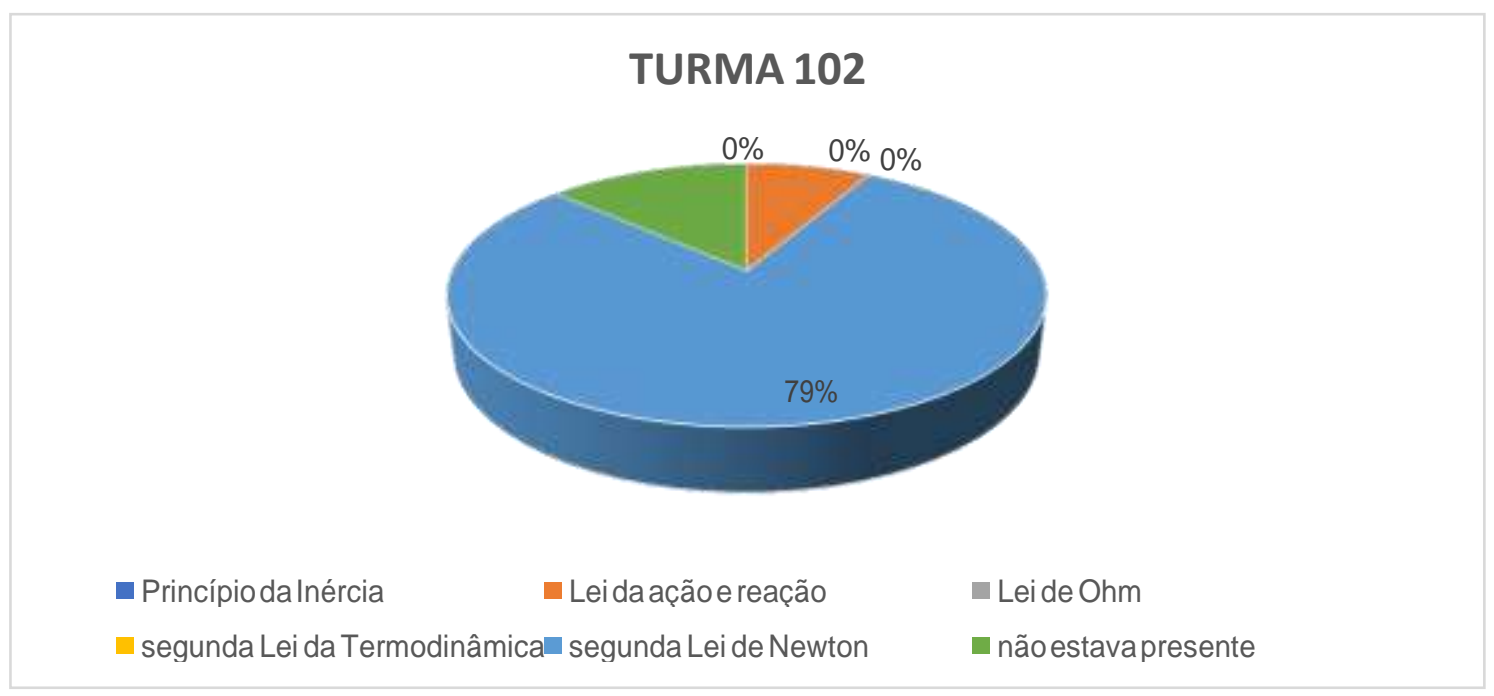

Fonte: Autores (2018).

Todas as informações acima, que constam nos resultados, foram relacionadas à primeira aplicação do questionário realizado tanto na turma 101 quanto na turma 102, na escola Centro de Ensino Josélia Ramos de Almeida. A seguir serão representados os resultados do segundo encontro com ambas as turmas.

O segundo encontro aconteceu com o intuito de discutir com os alunos sobre as experiências propostas pela presente pesquisa, proposta essa que tinha como objetivo, propor aos alunos que no período de uma semana começassem a observar a sua trajetória cotidiana, desde o começo até o fim do dia. E com isso, foi realizado o segundo encontro, a maioria dos alunos trouxeram suas anotações, tiveram alguns alunos que não fizeram, mas pelo a maioria fez, e mostraram interesse em seguir adiante com suas participações na pesquisa. Segue abaixo uma representação gráfica de cada turma (turma 101 e 102).

\section{Turma 101:}

Gráfico 25: percentual dos alunos participantes da pesquisa.

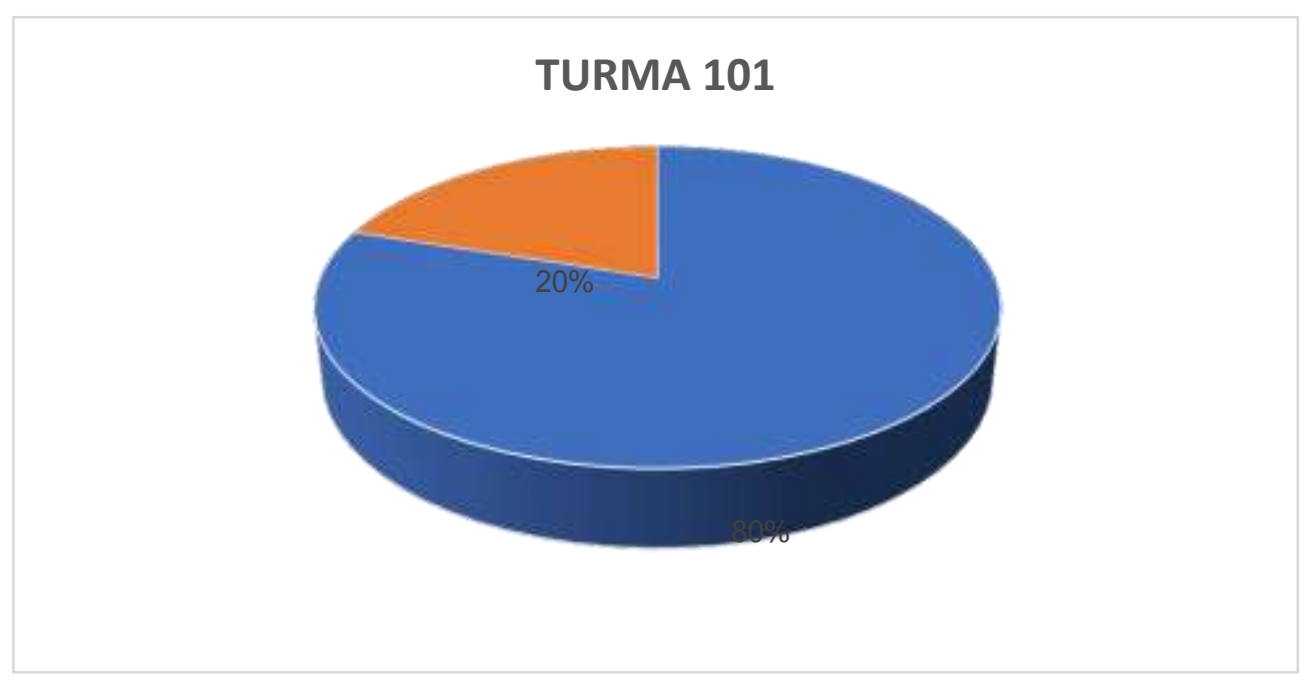

Fonte: Autores (2018). 


\section{Turma 102:}

Gráfico 26: Percentual dos alunos participantes da pesquisa.

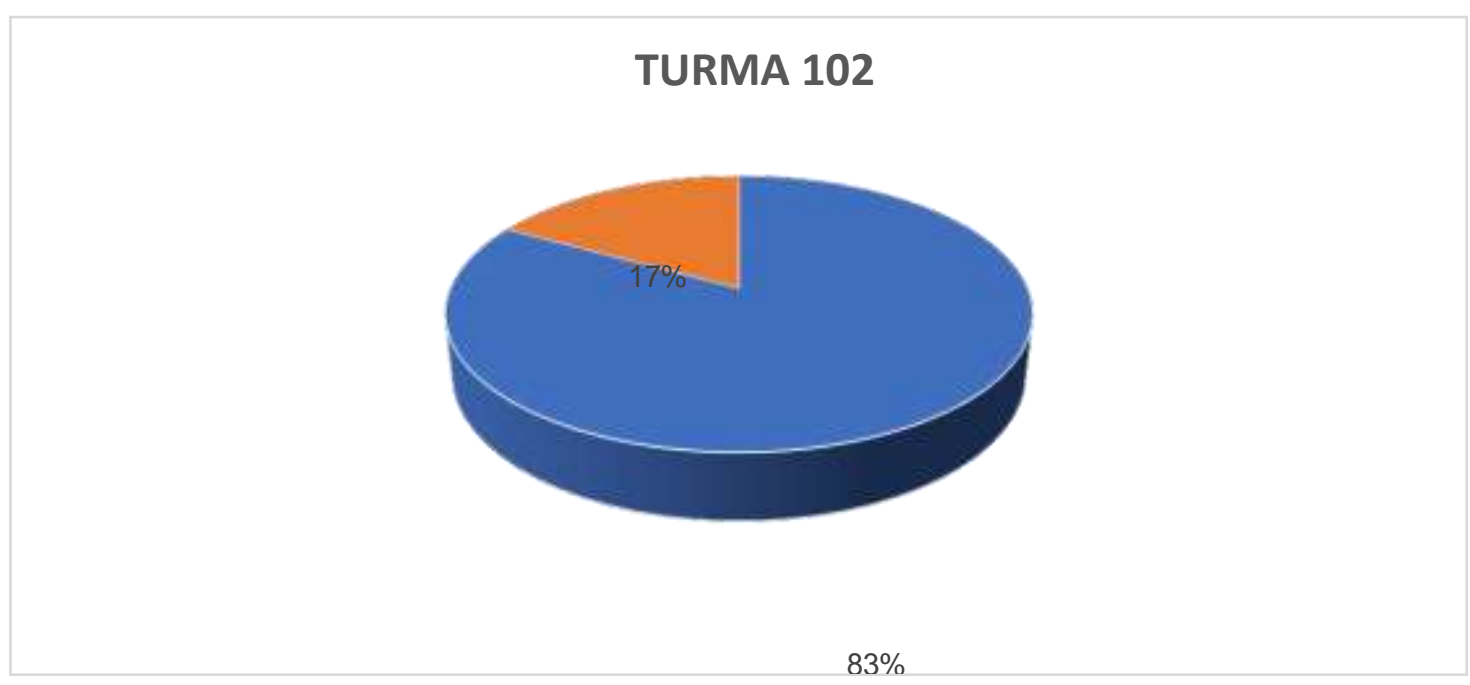

Fonte: Autores (2018).

Com isso, podemos perceber que o objetivo da nossa pesquisa, já começaram a serem alcançados desde já, pois como resultados tivemos que a grande maioria da turma, trouxeram suas anotações com as observações feitas. Com isso, o segundo momento da aula foi a discussão sobre os pontos, situações, vivenciadas que foram observadas no decorrer dessa experiência. Muitos alunos citaram que desde quando nasceu essa foi a primeira vez que parou para observar as coisas que fazem no decorrer da sua vida. Alguns comentários da turma 101, foram:

$>$ "professora em toda a minha, nunca tinha parado para observar porque tantas coisas acontecem, como exemplo nunca tinha parado para observar que o fato de empurrar uma mesa, isso já tem um porque, um significado, uma explicação, parei para observar que você disse que a segunda Lei de Newton, envolve tudo aquilo que eu tenho que exercer força para que um determinado objeto entre em movimento, e que ao exercer força, este consequentemente adquirirá uma aceleração. Com isso pude observar que quando eu empurrei a minha cama para arrumar o quarto, e nesse momento ela entrou em movimento, e quando eu empurrei a empurrei a cadeira ela se moveu com mais força, quero dizer assim, que ela se moveu com mais facilidade, ou tive uma maior facilidade em empurrá-la, enfim, quero dizer que hoje consigo ver que realmente a física se faz presente na minha vida, e lhe agradeço por ter me ajudado a perceber isso, e também a segunda Lei de Newton, é um conteúdo que nunca vou esquecer, porque foi o conteúdo que me fez ver que eu posso aprender sim física".

Acima as palavras da aluna que se mostrou tão deslumbrada com aquilo, que mostrou uma empolgação tão grande para aprender física, que alegrou meu coração, em ver tamanha satisfação.

Outro comentário relevante foi:

"professora, eu lhe afirmo com toda a certeza que eu já estava crente que nunca aprenderia física e que muito menos 
poderia enxerga-la em situações tão simples e comuns da minha vida, do meu dia a dia, mas lhe confesso agora, que essa experiência foi assim... um empurrão para que eu acordasse e pudesse ver que a física é sim possível de ser aprendida, e eu quero muito aprender mais, nunca imaginei que uma pequena fórmula como essa ( $\mathrm{f}=\mathrm{m} . \mathrm{a})$, pudesse me dar a explicação para tantas coisas, falei para os meus pais, e até eles acharam interessante, e com certeza vou dizer sempre que aprendi a buscar mais um pouco de física, através dessa tão pequenina lei, que nos traz tanto conhecimento.

"professora, todos os dias eu ajudo minha mãe arrumar a casa, e todos os dias a gente, arrasta cadeira, empurra sofá, mesa, para limpar a poeira dos móveis desde os mais maneiros aos mais pesados, mas nesses meus 16 anos de idade nunca, mas nunca mesmo podia imaginar que só o fato da gente empurrar, um ou dois objetos, eu já estou vivenciando a física, ah professora, isso foi demais, e eu achando que sou burra, porque não conseguia aprender a física, e muito menos tirar notas boas na mesma, é.... Mas eu preferia que as aulas fossem assim, mais dinâmica, onde eu pudesse ter experiências com essas de novo.... os outros assuntos podem ser também estudados assim” ...

“professora, essa semana de experiência, eu pude parar e observar que para aprender a física, não é só ter que copiar o conteúdo que está ali no quadro, na verdade isso é chato, e me faz ver que a física não é tão interessante assim... mas estava falando, essa semana foi tão diferente, observei os mínimos detalhes, as coisas que eu fazia no meu cotidiano, e pude observar o tanto de coisa legal que faço, e que todas elas tem uma explicação, e a segunda Lei pôde explicar muita que eu fiz, porque pelo que eu aprendi, ela enuncia que a força que eu aplico em determinado objeto, resulta em uma aceleração, que essa aceleração será maior ou menor dependendo da massa, então observei que quando empurro o carrinho de bebê domeu irmãozinho, o fato dele se mover pode ser explicado através da segunda Lei de Newton, outro exemplo que pude observar também, foi quando eu chuto uma caixa ocupada e uma caixa vazia, a aceleração na caixa vazia foi maior, então isso pode também ser explicado por meio da segunda Lei Newton, né isso?”.

Observando os comentários acima, podemos perceber que a experiência proposta foi realmente muito relevante para o desenvolvimento de ambos os alunos participantes da pesquisa. Veremos na tabela abaixo, algumas situações observadas pelos alunos que não discutiram em sala (os mais tímidos e reservados) mas que trouxeram suas anotações:

Tabela 3 - Experiências vivenciadas pelos alunos, onde a segunda Lei de Newton se faz presente - Turma 101.

\begin{tabular}{|l|l|}
\hline Aluno A & "Empurrar o carrinho de mão". \\
\hline Aluno B & "Empurrar minha moto que furou o pneu na estrada". \\
\hline Aluno C & $\begin{array}{l}\text { "trocar as camas de lugar, observei que ao trocar a cama da minha mãe tive } \\
\text { um pouco de dificuldade, mas ao trocar a minha tive mais facilidade, acredito } \\
\text { que a segunda Lei de Newton, pode explicar o porquê de isso acontecer". }\end{array}$ \\
\hline Aluno D & $\begin{array}{l}\text { "fui ao supermercado fazer comprar com minha avó, e eu que ficava com o } \\
\text { carrinho empurrando, então acredito que essa é uma situação em que a } \\
\text { segunda Lei de pode explicar". }\end{array}$ \\
\hline
\end{tabular}

Fonte: Autores (2018). 
E nesse caso, tem-se também no mesmo contexto, que:

Tabela 4 - Experiências vivenciadas pelos alunos, onde a segunda Lei de Newton se faz presente - Turma 102.

\begin{tabular}{|l|l|}
\hline Aluno A & $\begin{array}{l}\text { "quando vamos movimentar uma cadeira, mesa ou qualquer outro objeto que } \\
\text { necessite de movimento para ter uma aceleração, precisamos exercer uma força } \\
\text { sobre tal objeto, para que ele entre em movimento, isso é a segunda Lei de Newton. } \\
\text { eu pude ver que quando meu tio estava com o carro quebrado, ele teve que } \\
\text { empurrar juntamente com outras pessoas, lembro-me que eles tiveram dificuldade } \\
\text { para mover esse carro do lugar, e isso se deve à massa do objeto porque o carro é } \\
\text { muito pesado, pois quanto } \\
\text { maior a massa menor a aceleração". }\end{array}$ \\
\hline Aluno B & $\begin{array}{l}\text { "ao empurrar ou mover a cadeira da sala da } \\
\text { minha casa, eu exerci força sobre ela para que ela entrasse em movimento". }\end{array}$ \\
\hline Aluno C & $\begin{array}{l}\text { "ao mover a mesma de um lugar para outro, eu exerci força e, portanto, a mesa teve } \\
\text { uma aceleração quando se movimentou, então isso acontece por causa da segunda } \\
\text { Lei de } \\
\text { Newton". }\end{array}$ \\
\hline Aluno D & $\begin{array}{l}\text { "observei que minha Mãe pratica a segunda Lei de Newton todos os dias, e até pois } \\
\text { todo dia a gente faz algum objeto se movimentar, um exemplo é quando eu } \\
\text { arremessei um boné, e em seguida um livro, tive mais dificuldade em arremessar o } \\
\text { livro do que o boné, isso acontece porque um livro é mais pesado que um boné, e } \\
\text { isso pode ser melhor explicado através dasegunda Lei de Newton". }\end{array}$ \\
\hline
\end{tabular}

Fonte: Autores (2018).

Portanto, é possível perceber que nossa pesquisa obteve bons resultados no decorrer dessa nova experiência proposta para os alunos. Pois estes acataram tal experiência, o que os estimulou a vivenciá-la, foi a curiosidade em comprovar se realmente a física pudesse ser representada por meio da segunda Lei de Newton. Com isso, começaram a observar possíveis situações onde a física e a segunda Lei de Newton estivesse presente. Ao trazerem para a sala de aulas seus relatos, mostraram que tem sim interesse de aprender física, mas de uma maneira mais dinâmica, que fizesse com que os alunos fossem os autores da situação. Nos relatos acima, pode-se observar que eles se mostraram muito interessados, irados, surpresos e ao mesmo tempo satisfeitos em poder ter tido uma oportunidade de ver a física e seus fenômenos de uma forma diferente. De poder saber que a física está presente até mesmo ao empurrar sua cama.

Diante disso, foi possível despertar o interesse dos alunos em aprender, conhecer um pouco mais sobre a física, e foi também possível perceber que eles não aprendem não é porque não querem aprender, e sim pelo muito ouvir falar de que não se pode aprender física, por ela ser muito complicada e se não há nenhuma forma, nenhuma atitude, experiência, atividade, ou conversa se quer que comprove o contrário, ou que os mostre o oposto, a tendência é afirmar essas certezas hipotéticas que vão passando de geração em geração. Se realmente não fosse do interesse desses alunos aprender física, certamente eles não tinham aceitado participar da presente pesquisa, pois a todos os alunos foi entregue um termo de consentimento para que os alunos, ou os responsáveis por eles, assinassem como autorização de incluí-los nessa experiência.

Seus relatos foram muito interessantes, falaram por meio de palavras simples, o que estavam sentindo com a presente experiência, mas essas palavras simples conseguiram expressar que estavam gratos por essa oportunidade, e que serviu para 
observar mais sua rotina diária, se auto questionar porque determinadas coisas acontecem, e que em meio a esses questionamentos, a física se faz presente em boa parte deles. Podemos ver que houve outro ponto importante e satisfatório para o intuito da pesquisa, pois alguns dos relatos diziam que nunca irão esquecer de que a segunda Lei de Newton foi o que despertou um maior interesse pela física para muitos dos alunos ali presentes.

O próximo e último encontro se deu para a aplicação do último questionário em ambas as turmas (101 e 102) de primeiro ano. Esse questionário aconteceu com intuito de verificar a real aprendizagem dos alunos quanto ao tema da pesquisa. Todas as questões deste eram discursivas, onde os alunos teriam a oportunidade de se expressar diante do tema da pesquisa e da experiência vivida, proposta pela pesquisa. Com isso, serão apresentados abaixo os resultados do questionário aplicado para estes alunos.

A primeira questão indagava os alunos baseadas nas observações feitas durante esse período de uma semana proposto pela pesquisa. O que eles poderiam dizer a respeito da Mecânica Newtoniana. As opções de respostas eram sim ou não, e escolhido umas das opções eles poderiam justificar suas respostas. Como resultado temos consecutivamente:

\section{Turma 101:}

1. Sim: $72 \%$ dos discentes.

2. Não: $24 \%$ dos discentes.

3. Não estava presente: $4 \%$ dos discentes.

\section{Turma 102:}

1. Sim: $54 \%$ dos discentes.

2. Não: $26 \%$ dos discentes.

3. Não fizeram ou não estavam presente: $20 \%$ dos discentes.

A segunda questão pedia que os alunos citassem algumas situações que eles identificaram no decorrer dessa experiência proposta por a presente pesquisa. Abaixo estão descritos alguns dos relatos feitos pelos alunos:

1. "Eu presenciei um caso em que minha prima falou que a estava andando na rua com a tia dela dirigindo e vinha uma moto em alta velocidade, ela freou repentinamente, isso eu aprendi que a segunda Lei de Newton se faz presente, pois nesse caso no momento em que a tia dela freou houve uma aceleração. Aprendi isso de acordo com alguns exemplos em que você professora Jade citou para na última aula".

2. "Eu fui ao supermercado com minha Mãe e ao pegar o carrinho para colocar as compras, ele ia ficando ainda mais pesado, e fazia com que eu exercesse mais força para poder movimentá-lo”.

3. “fui ajudar a tia a fazer mudança da casa dela, e ajudamos ela e meu tio a mudar os móveis e com isso a gente empurrou muito objeto, exercemos muita força, e quanto mais pesado era o móvel, mais força tínhamos que exercer, e também quando o móvel era leve ele tinha uma maior aceleração, se movimentava mais rápido. Eu consegui ver por meio das explicações dadas por você professora Jade, que a segunda Lei de Newton está presente em situações simples como essa".

4. "eu fui jogar futebol e quando chutei a bola, percebi (obs.: coisa que fazia diariamente, mas que nem ligava para saber porque acontecia) que quando eu chutei a bola, eu exerci força para que ela entrasse em movimento. Agora eu já me 
despertei para observar mais minha rotina, me questionar mais sobre os porquês da vida. Obrigada professora Jade por me ajudar a entender que a física está até no que eu mais gosto de fazer, que é jogar futebol, nunca vou esquecer de você, uma professora excelente".

A terceira questão perguntava aos alunos se no decorrer dessa experiência vivida e de acordo com as observações feitas, eles tinham identificado situações em que a segunda Lei de Newton, se faz presente. Como alternativa tinham então, sim e não e pedia que em caso afirmativo os alunos pudessem citar pelo menos uma delas. No entanto,

\section{Turma 101:}

1. Sim: $80 \%$ dos discentes.

2. Não: $16 \%$ dos discentes.

3. Não fizeram ou não estavam presente: $4 \%$ dos discentes.

\section{Turma 102:}

1. Sim: $56 \%$ dos discentes.

2. Não: $24 \%$ dos discentes.

3. Não fizeram ou não estavam presente: $20 \%$ dos discentes.

A quarta questão era que os alunos fizessem um comparativo quanto aos seus conhecimentos anteriores e atuais sobre a segunda Lei de Newton, e se eles consideram que houve um avanço na sua aprendizagem ou não, e abria espaço ainda, para que eles justificassem sua resposta de forma livre, a expressar suas opiniões. Como resultados das turmas 101 e 102, consecutivamente, temos:

\section{Turma 101:}

1. Sim: $80 \%$ dos discentes.

2. Não: $16 \%$ dos discentes.

3. Não fizeram ou não estavam presente: $4 \%$ dos discentes.

\section{Turma 102:}

1. Sim: $54 \%$ dos discentes.

2. Não: $26 \%$ dos discentes.

3. Não responderam ou não estavam presente: $20 \%$ dos discentes.

A quinta questão pergunta se os alunos concordam que a segunda Lei de Newton possa ser um dos elos principais para estimular o interesse destes pela disciplina de física, e como alternativas poderiam responder sim ou não e poderiam ainda justificar suas respostas. Com isso, foram-se obtidos os seguintes resultados:

\section{Turma 101:}

1. Sim: $96 \%$ dos discentes. 
2. Não: $0 \%$ dos discentes.

3. Não fizeram ou não estavam presente: $4 \%$ dos discentes.

\section{Turma 102:}

1. Sim: $80 \%$ dos discentes.

2. Não: $0 \%$ dos discentes.

3. Não fizeram ou não estava presente: $20 \%$ dos discentes.

A sexta questão pergunta se a partir da pesquisa: "A segunda Lei de Newton: teoria versus aplicação no cotidiano". Ajudou-os a quebrar alguns dos paradigmas dados à física, tais como: "a física é coisa de loucos", "a física é uma disciplina difícil de ser compreendida", etc. como resultado temos que:

\section{Turma 101:}

1. Sim: $76 \%$ dos discentes.

2. Não: $20 \%$ dos discentes.

3. Não fizeram ou não estavam presente: $4 \%$ dos discentes.

\section{Turma 102:}

1. Sim: $60 \%$ dos discentes.

2. Não: $20 \%$ dos discentes.

3. Não fizeram ou não estiveram presente: $20 \%$ dos discentes.

A sétima questão perguntava aos alunos se caso eles fossem prestar vestibular hoje, baseados nos conhecimentos adquiridos durante a presente pesquisa, eles teriam um bom resultado. Como alternativas poderiam marcar sim ou não e ainda poderiam justificar suas repostas. Abaixo serão representados os resultados das turmas, obtidos para essa questão.

\section{Turma 101:}

1. Sim: $48 \%$ dos discentes.

2. Não: $48 \%$ dos discentes.

3. Não fizeram ou não estiveram presente: $4 \%$ dos discentes.

\section{Turma 102:}

1. Sim: $50 \%$ dos discentes.

2. Não: $30 \%$ dos discentes.

3. Não fizeram ou não estavam presente: $20 \%$ dos discentes.

A oitava e penúltima questão, perguntava aos alunos se o tema da presente pesquisa os estimulou a buscar conhecer mais sobre a física e seus fenômenos naturais. As alternativas também eram sim ou não. Os resultados obtidos foram: 


\section{Turma 101:}

1. Sim: $60 \%$ dos discentes.

2. Não: $36 \%$ dos discentes.

3. Não fizeram ou não estavam presente: $4 \%$ dos discentes.

\section{Turma 102:}

1. Sim: $78 \%$ dos discentes.

2. Não: $2 \%$ dos discentes.

3. Não fizeram ou não estavam presente: 45 dos discentes.

A última questão, perguntava se os alunos acreditam que a presente pesquisa contribui positivamente para estimular o aluno a ter um maior interesse pela disciplina de física. Também poderiam responder sim ou não. Portanto, tivemos os seguintes resultados:

\section{Turma 101:}

1. Sim: $84 \%$ dos discentes.

2. Não: $12 \%$ dos discentes.

3. Não fizeram ou não estavam presente: $4 \%$ dos discentes.

\section{Turma 102:}

1. Sim: $76 \%$ dos discentes.

2. Não: $4 \%$ dos discentes.

3. Não fizeram ou não estiveram presente: $20 \%$ dos discentes.

Diante dos resultados acima, pode-se perceber que a pesquisa conseguiu obter ótimos resultados. Pois esta conseguiu despertar, estimular o interesse dos alunos em aprender mais sobre a física. Conseguiu ainda, fazer com que os alunos se tornassem autores dos seus próprios relatos, fazendo com que eles mesmo buscassem, procurassem os fenômenos da física, isso foi importante para eles, relataram coisas que jamais imaginaram fazer, perceber. E por meio de um conteúdo que parece ser tão simples que é a segunda Lei, eles puderam ver esse outro lado da física. Alguns até relataram não esquecer que a aprenderam, se imaginaram dentro da física, perceberam a presença desta na sua vida, por meio da segunda Lei de Newton. isso fez com que os objetivos da pesquisa fossem alcançados com sucesso.

Foi possível também identificar nos alunos que o grande ponto que faltava era alguém para lhes mostrar o lado mais dinâmico de se aprender física, e com isso mais um objetivo da pesquisa foi alcançado, isto é, conseguimos trazer para os alunos uma nova forma, uma nova metodologia de ensino que deveria ser usada pelo menos alternadamente, para fazer com que os alunos também possam participar ativamente das aulas, para que eles se sintam importantes contribuintes nas aulas. Não foi dito aqui, que não se deve trabalhar o ensino tradicional, pelo contrário deve sim, pois foi a partir deste que a educação começou a andar. Mas se torna mais interessante quando o professor tem algo novo, uma metodologia nova para partilhar com os seus alunos, chamando-os para participar, de cada encontro com a sala. 


\section{Considerações Finais}

Portanto, pode-se constatar que a presente pesquisa alcançou os principais objetivos almejados, pois os alunos se mostraram bastante interessados em participar desta. Eles conseguiram enxergar a física ao seu redor, puderam comprovar que realmente a física faz parte do seu cotidiano. Afirmaram que a segunda Lei de Newton, certamente foi o elo principal que os motivou a se imaginar dentro da física, a comprovar a existência dos fenômenos naturais por meio da nomenclatura da segunda Lei de Newton.

Além disso, a presente pesquisa conseguiu despertar o interesse dos discentes em observar mais as suas práticas diárias, levar a disciplina de física mais a sério. Isso torna-se bastante satisfatório, pois até então, praticamente todos os alunos participantes da pesquisa não gostavam ou não se interessavam pela disciplina. as mais frequentes justificativas foram que não viam nada de interessante nesta, enxergavam apenas cálculos, difíceis e complicados de serem entendidos e resolvidos. Disseram ainda, que os conteúdos sempre eram expostos da mesma forma, alegando que sempre ouviam a mesma coisa, que a física estava presente, no cotidiano de todos os seres humanos, que a física fazia parte da vida do ser humano, mas ninguém nunca os mostrou, comprovou essa presença e essa participação da física e seus fenômenos naturais presentes nas suas atividades diárias.

Foi possível ainda, perceber que os alunos precisavam ser chamados, convidados a participar dessa comprovação de existência dos fenômenos físicos naturais. Mostraram que tem interesse em aprender, no entanto preferem a prática, aplicação desses conteúdos presentes na física. Muitos alegaram que a segunda Lei de Newton era para a grande maioria deles apenas mais uma lei da física, acrescentaram ainda, que jamais imaginaram algo de interessante nesta. Porém, hoje pensam completamente diferente, já que foi por meio dessa simples lei, que conseguiram, que puderam conhecer, entender um pouco da disciplina e da física em si.

Diante do exposto acima, pode-se perceber que por mais simples, por menos interessante que pareça ser o conteúdo, o assunto em questionamento e análise, cabe ao público envolvido seja eles dirigentes ou não da ação em questão, tornar esse conteúdo, esse assunto mais complexo de forma a mostrar seus elos de ligação com o cotidiano com a vida da sociedade, de modo a envolver o máximo possível a vida dessas pessoas. Mostrando-os as maiores e mais complexas atividades beneficentes que determinado conteúdo pode trazer para a sociedade, e destacando suas relevâncias para a vida como um todo.

Com isso, pode-se destacar que diante dos resultados obtidos com a presente pesquisa, é notório que esta dispôs de um relevante e crescente resultado, com ênfase na positividade, isto é, obteve-se com a pesquisa, ótimo resultados o que faz dos objetivos a então referida, um sucesso. Como continuação para melhorar ainda mais os resultados desta, e como sugestão para um possível prosseguimento de coleta de dados para a pesquisa e ganhar um número ainda mais satisfatório em sua totalidade, seria a aplicação de experimentos com relação a segunda Lei de Newton. isso porque os alunos demonstraram que os seus maiores interesses é participar, é contribuir com sua participação, o que para eles torna-se algo bastante relevante.

\section{Referências}

Araújo, F. L. (2008). Laboratórios didáticos de física em nível médio na região de Ituiutaba-MG: Levantamento dos recursos e proposta de atividades. USP.

Araújo, L. N.. (2014). O ensino de física e a tecnologia a partir das Leis de Newton. Brasília: UnB.

Bonadiman, H; \& Nonenmacher, S. E. B. (2007). O gostar e o aprender no ensino de física: uma proposta metodológica. Rio grande do Sul: UNIJUÍ.

Coelho, F. (2014). Física. Juiz de fora: UFJF. 
Research, Society and Development, v. 10, n. 2, e1321025727, 2021

(CC BY 4.0) | ISSN 2525-3409 | DOI: http://dx.doi.org/10.33448/rsd-v10i1.5727

Garcia, V. G. (2010). A gravitação universal na filosofia da natureza de Isaac Newton. UFP.

GREEF. (1998). Leituras de Física. São Paulo: USP.

Luz, A. M. R. (2013). Física contexto e aplicações: ensino médio.Scipione

Menezes, L.S.. (2016). Sequência didática para aprendizagem ativa das Leis de Newton. Sergipe: UFS.

Miranda, W.. L. A. (2014). Física geral I. IFB.

Pinto Neto, A. P. (2002). Notas de aula da disciplina mecânica teórica I. São Luís: UFMA.

Oliveira, R. A. P de. (1967). Isaac Newton. UFPB, abril de 2009. OREAR, Jay. Peso e massa.

Pietrocola, M. (2001). Ensino de Física. UFSC.

Rodrigues, G. O. (2016). Estágio supervisionado em ciências - um relato de experiências.: UEPB.

Silva, R. T. (2016). Notas de aula de física.

Silva, C. X.. (2008). Física aula por aula. Vol1,: FTD

Trivinos, A. N. S. (1987). Introdução à pesquisa em ciências sociais: a pesquisa qualitativa em educação. Editora - Atlas 